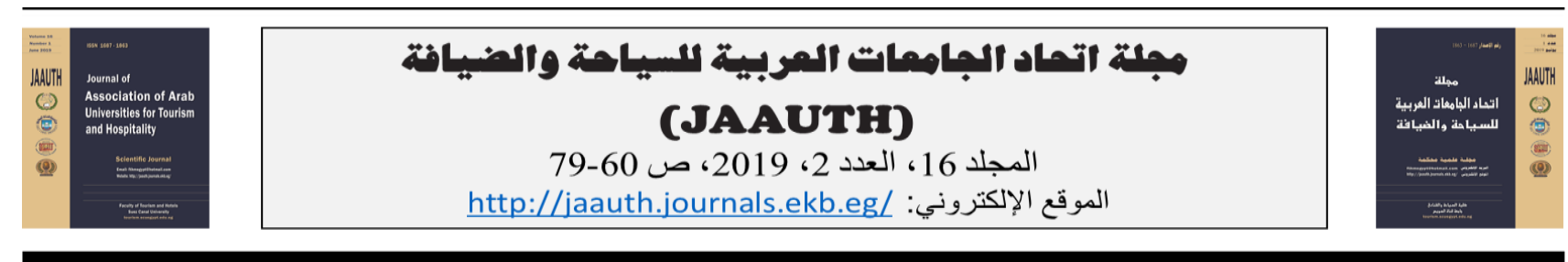

أثر بيئة العمل في الإبداع الإداري لاى العاملين بشركات العياحة المصرية

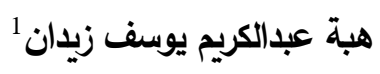

مدرس بقسم الدراسات السياحية بالمعهـ العالي للسياحة والفنادق وترميم الآثار ، أبو قير ، الإنكندرية

\begin{tabular}{|c|c|}
\hline & \\
\hline 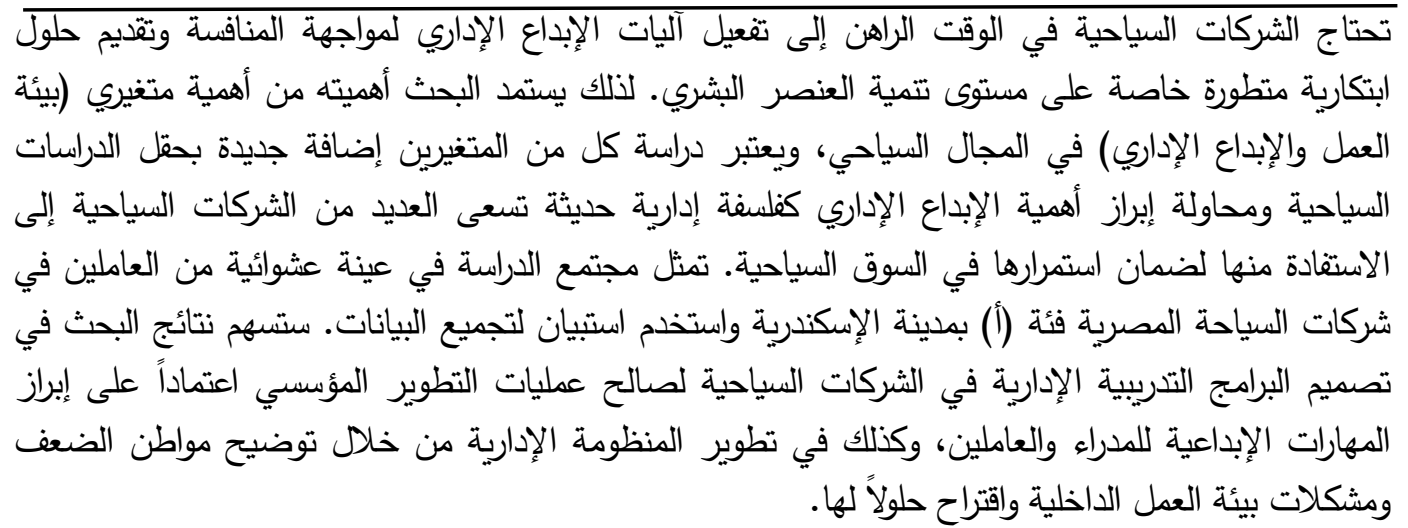 & $\begin{array}{c}\text { (JAAUTH) } \\
\text { (المجلد 16، العدد } 2 \text { (2019) } \\
\text { (79-60 }\end{array}$ \\
\hline
\end{tabular}

المقدمة

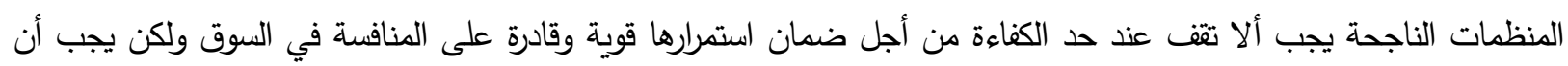

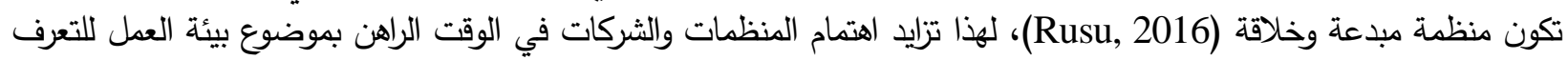

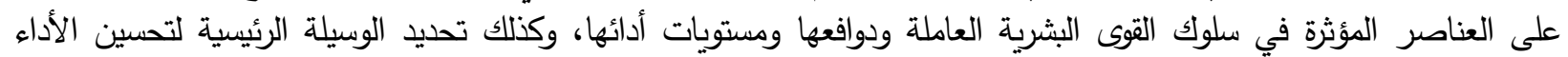

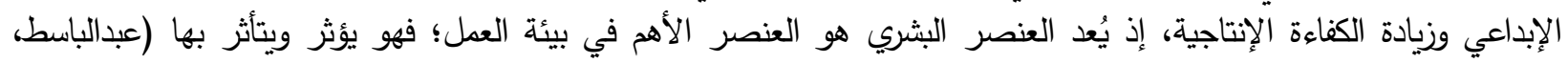

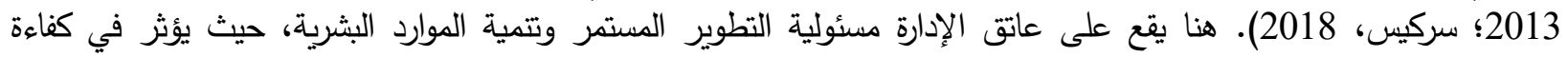

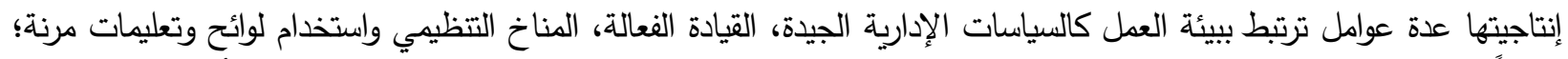

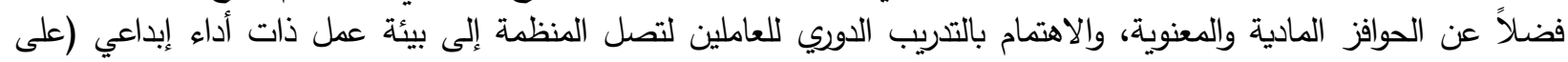

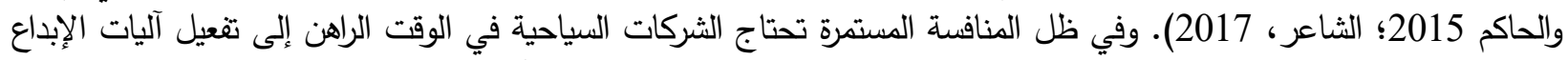

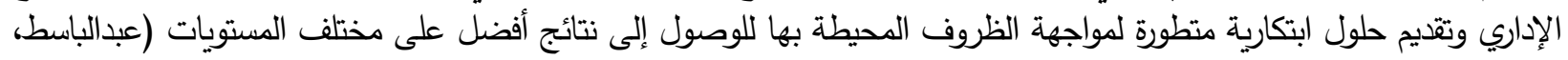

2013؛ يمينة، 2018).

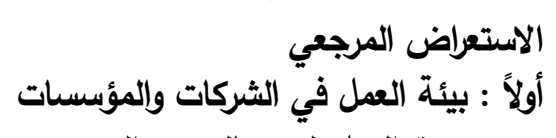

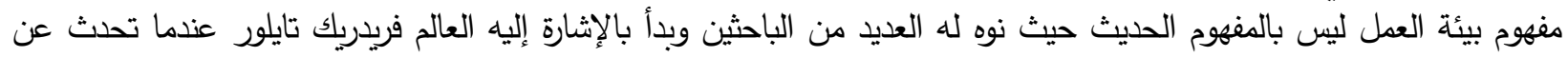

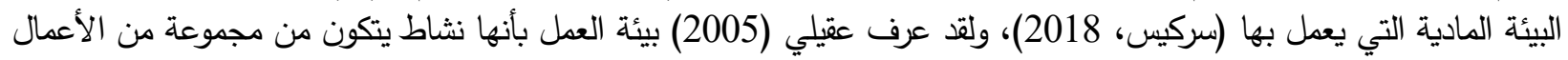

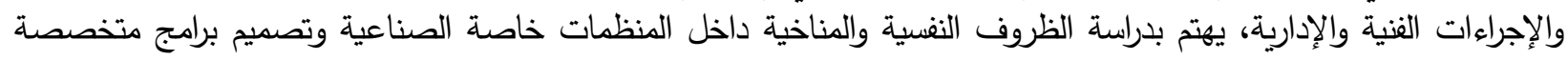

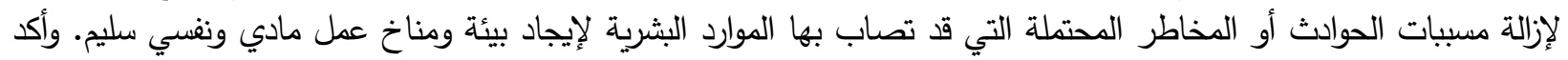

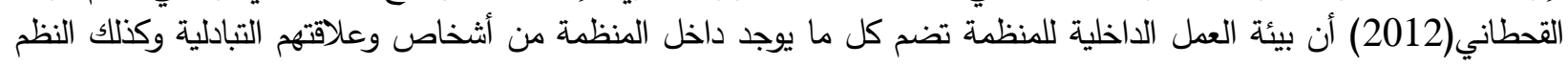

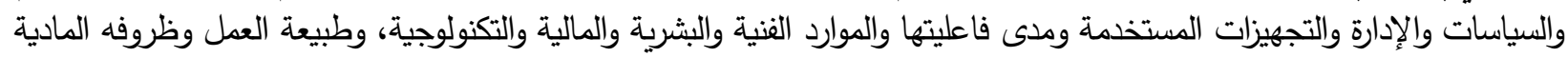

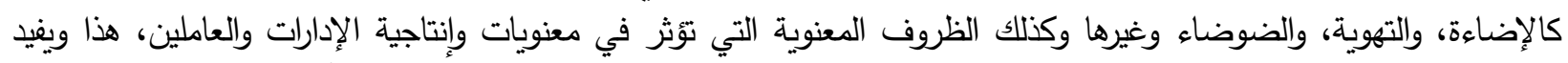

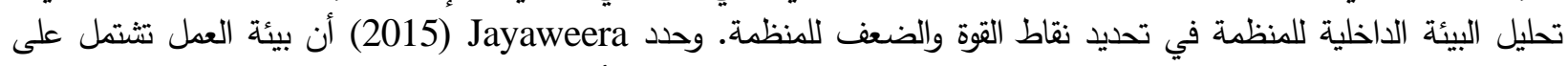
عنصري السلامة والصحة، إذ تثير السلامة إلى حماية الميلى الموارد البشرية من الأضرار التي تسبيها لهم حوادث محتملة في مكان

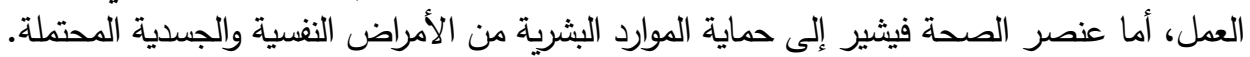
مكونات وأبعاد بيئة العمل تتكون بيئة العمل من الهيكل التنظيمي: ويقصد بهذا البعد البعل الإطار العام الذي يحدد المستويات الإدارية وأنظمة انسياب العمل

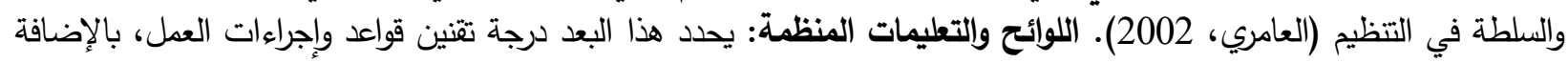

1 Heba zidaan@yahoo.com 
إلى تحديد الوثائق والأدلة التي تستخدها الإدارة لإنجاز الأعمال (عيسى،2014؛ إسماعيل،2014) .المشاركة في اتخاذ القرار:

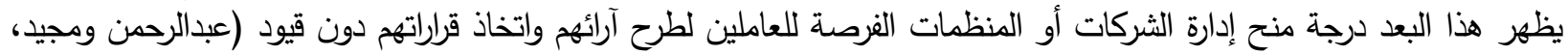

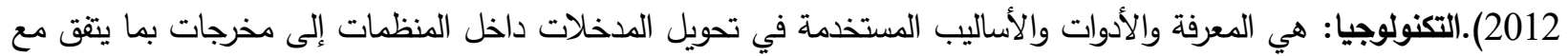

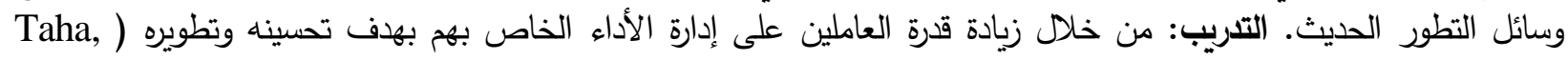

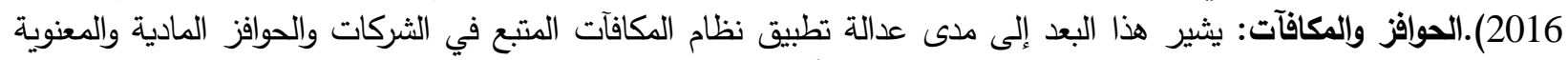

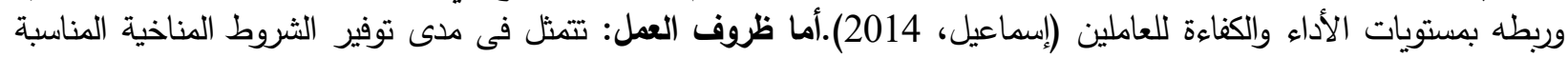

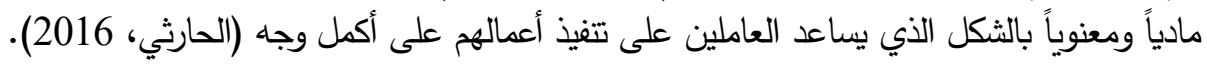
ثانياً: الإبداع الإداري يمثل الإبداع قدرة عقلية تظهر على مستوى الفالئل الفرد والجماعة والمنظمة ويمكن تتميته من خلال التدريب المستمر للأفراد وتوفير المناخ

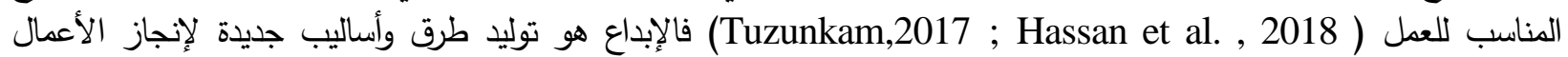

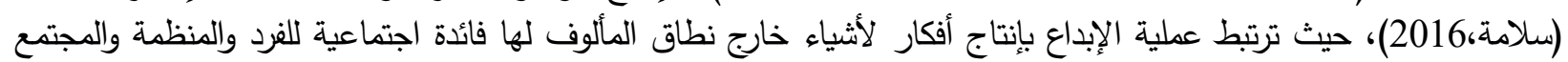

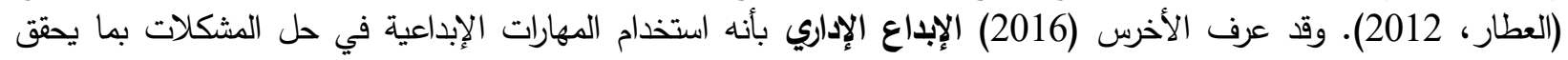

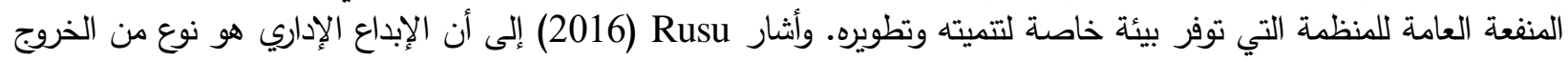

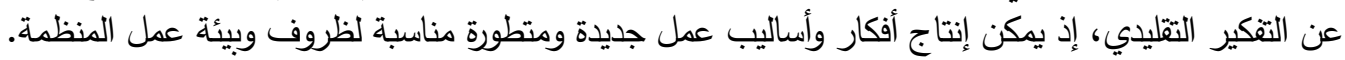

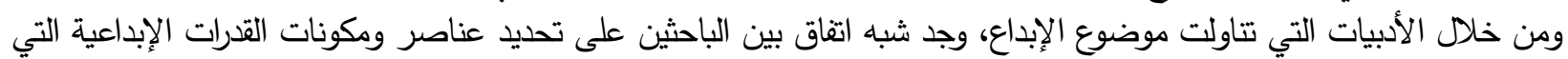

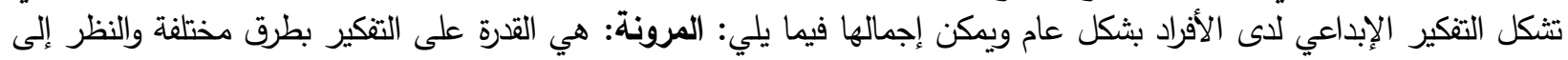

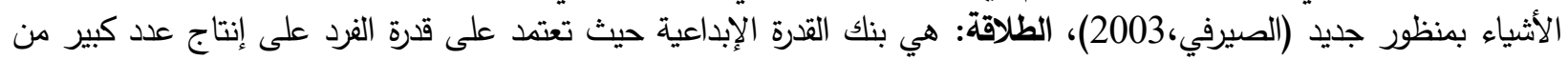

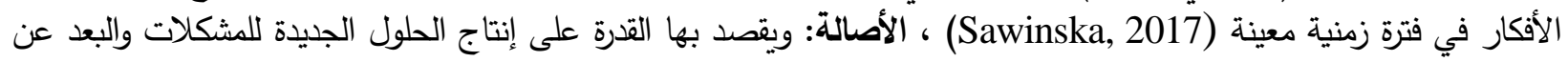

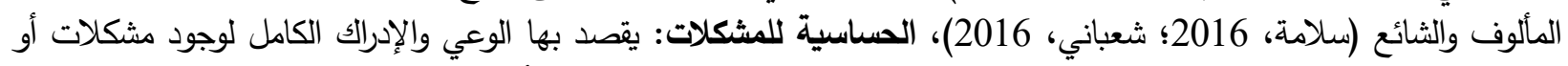

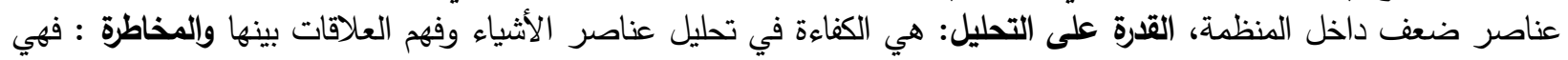

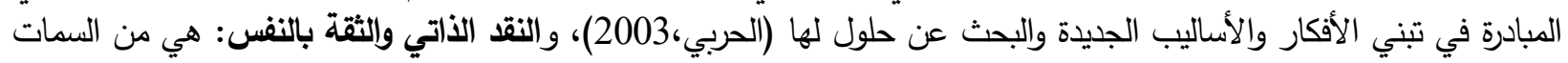

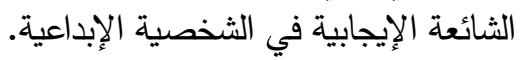
يظهر الإبداع الإداري في العديد من المستويات الإدارية داخل الثركات أو المنظمات سواء على المستوى الفردي حيث يتمتع العامل

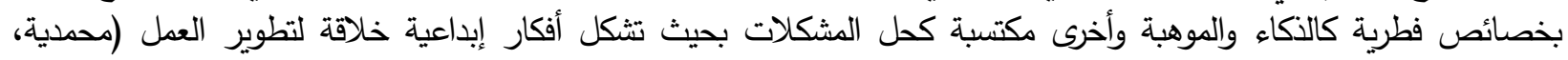

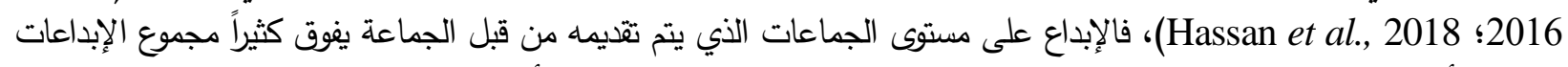

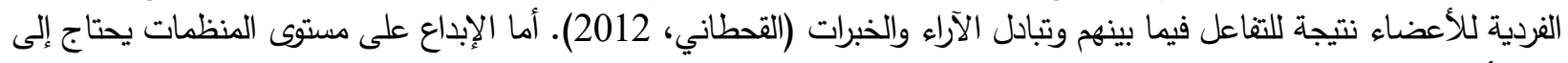

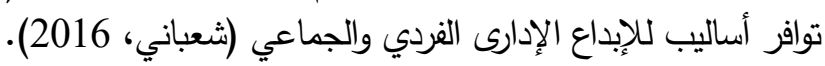
هذا ويتم التعرف على تطور الإبداع في الثركات السياحية من خلال عدة مؤشرات نذكر منها عدد الخدمات الجديدة التي تختلف في

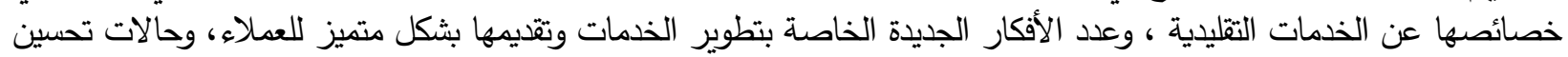

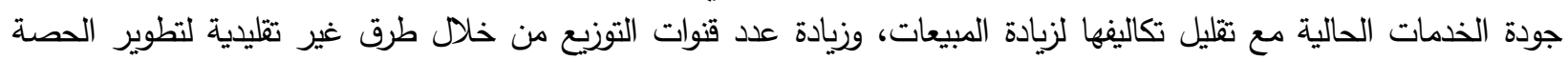

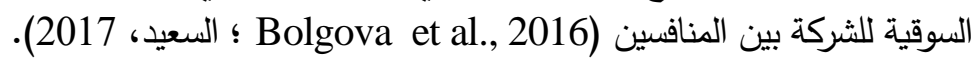

أنواع الإبداع الإداري وأهميته

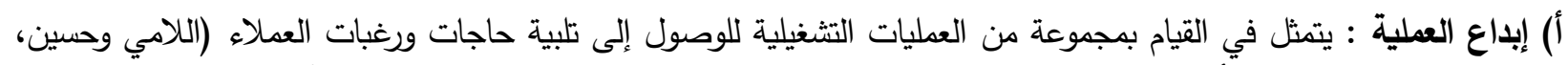

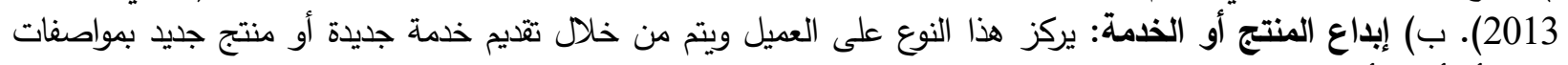

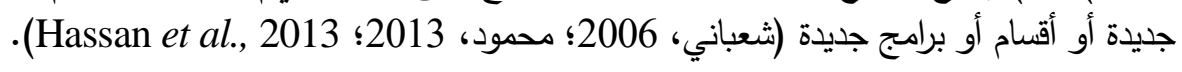

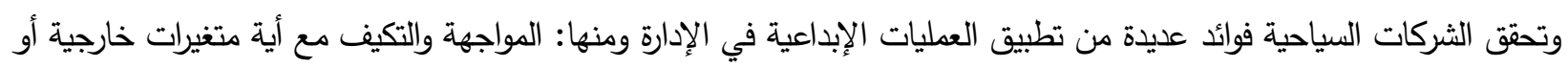

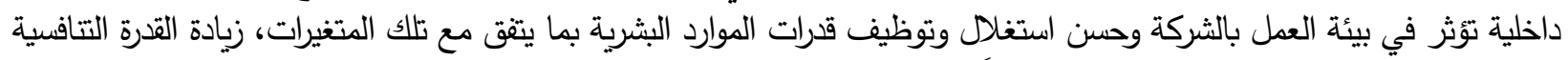

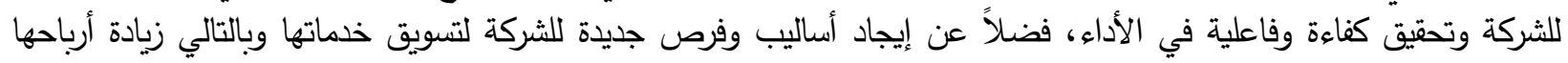

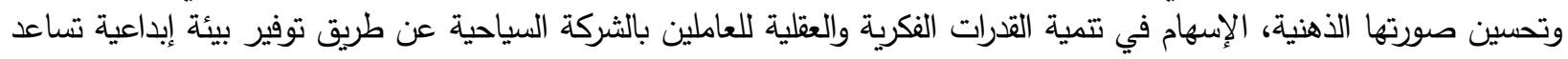

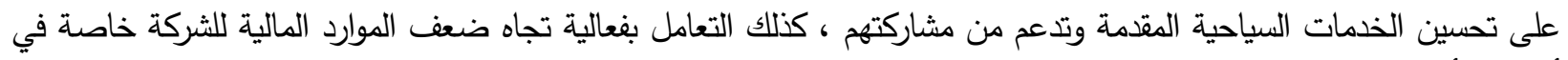

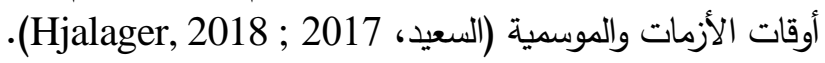


معوقات العملية الإبداعية الإدارية بالثركات السياحية

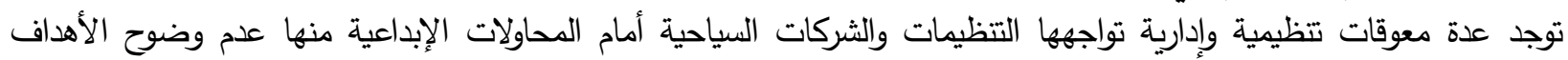

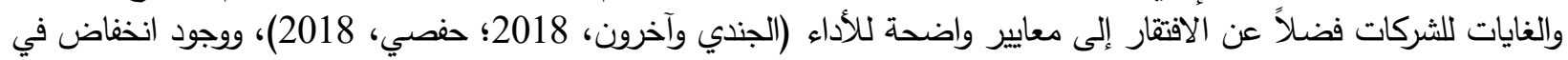

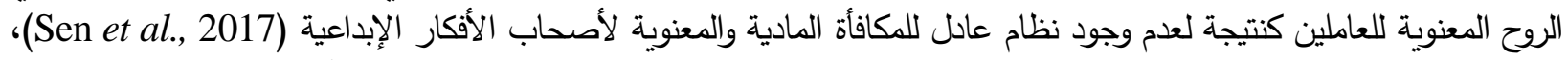

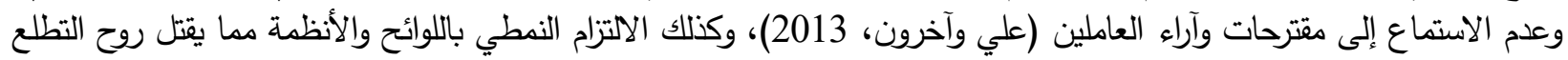

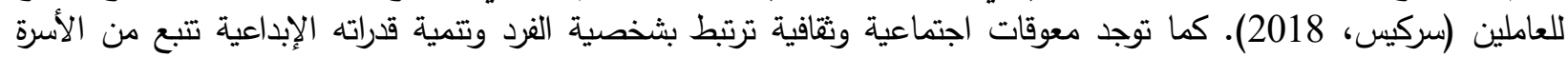

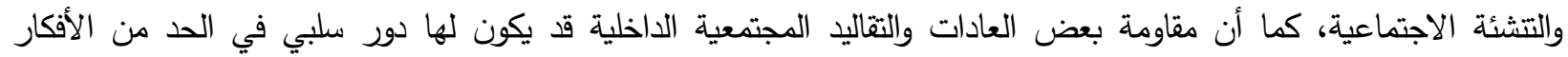

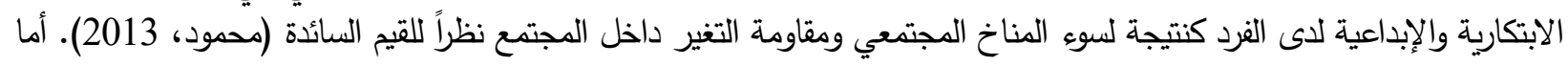

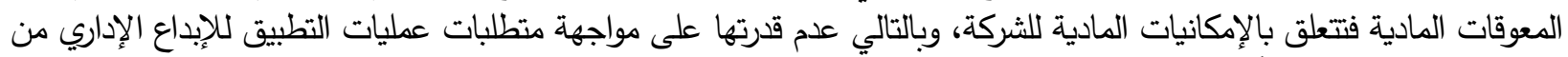

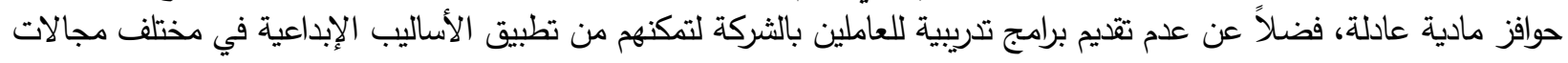

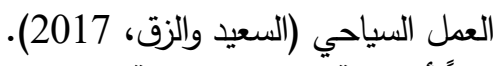

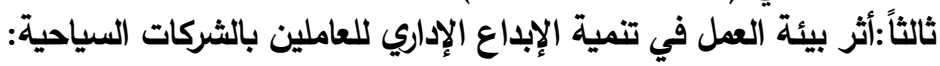

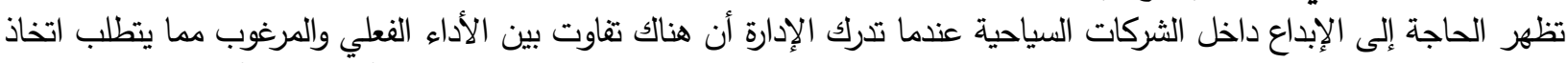

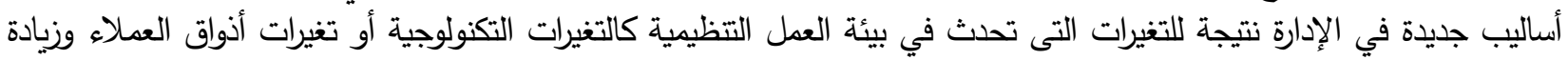

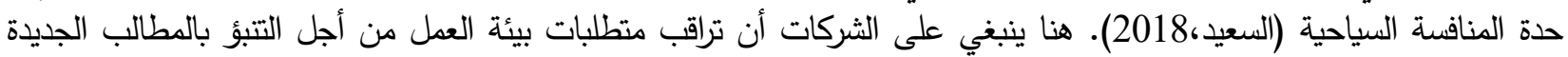

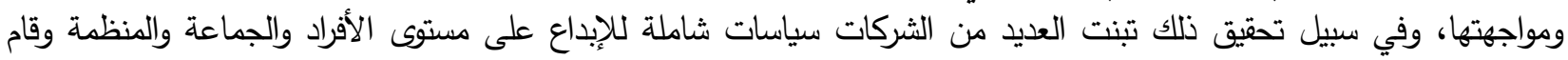
البعض بإنثاء وحدات تتظيمية خاصة مثل وحدات التطوير الإداري ، كما قامت شركات أخرى بتدريب الأفراد والمدراء على النيل السلوك

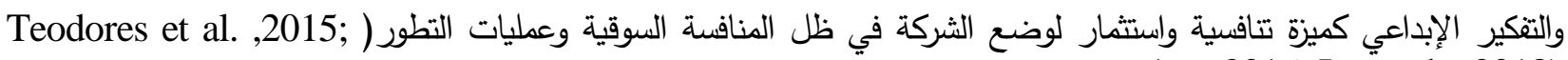
Aas, 2016; Izquerdo, 2018) مشكلة البحث

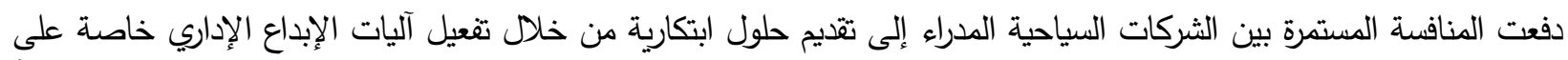

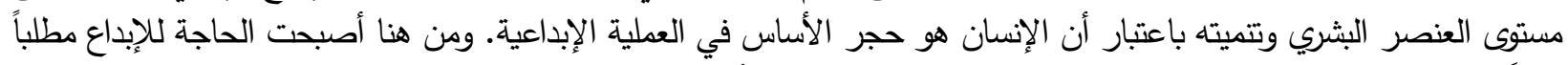

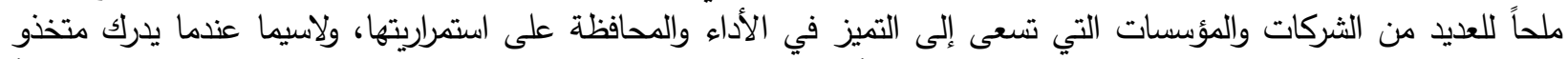

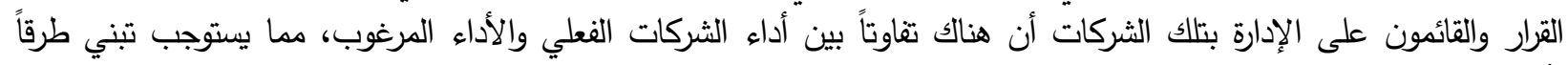

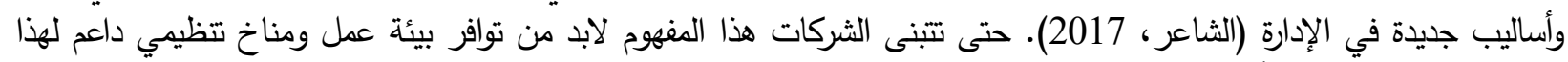

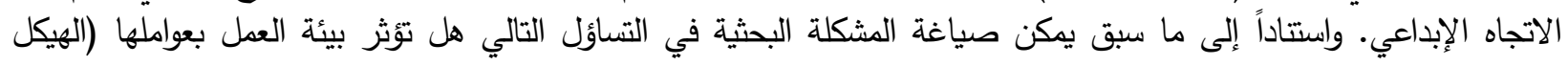

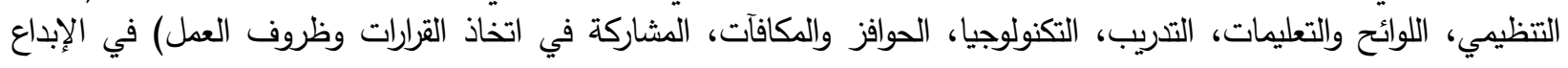
الإداري للعاملين بالثركات السياحية المصرية. التصرية. أهداف البحث الإدي

1. دراسة مستوى الإبداع الإداري لدى العاملين في الثركات السياحية المصرية؛

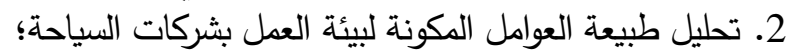

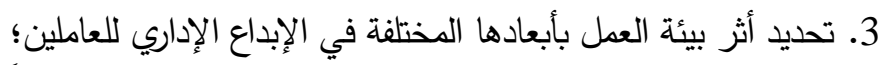

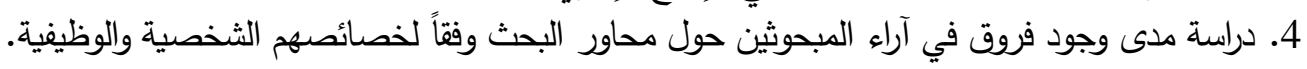
فروض البحث الفرض الرئيسي الأول

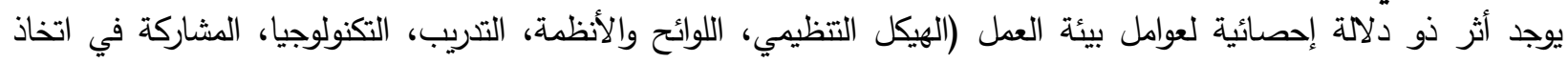

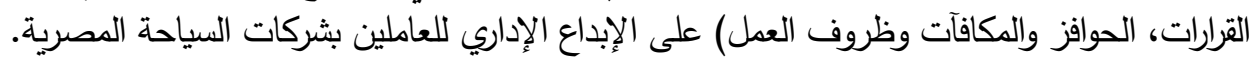
يثتق منه الفروض الفرعية التالية:

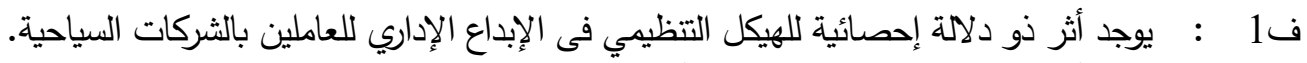

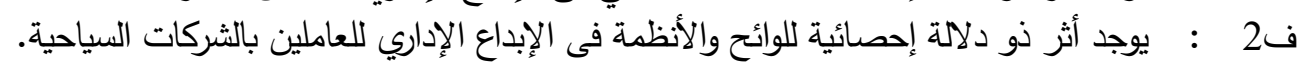

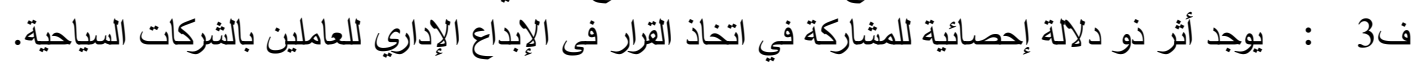

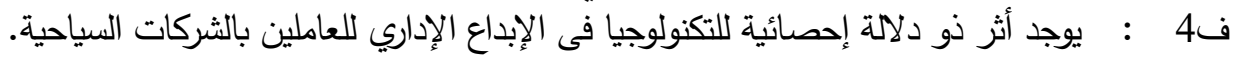

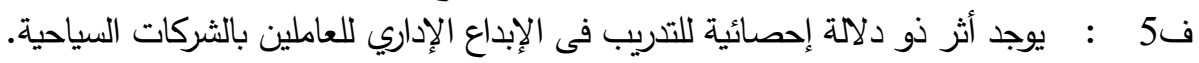

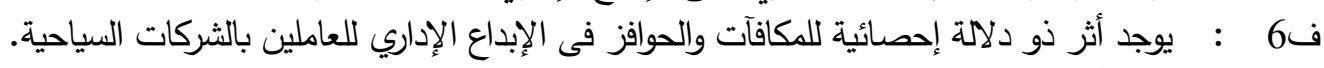

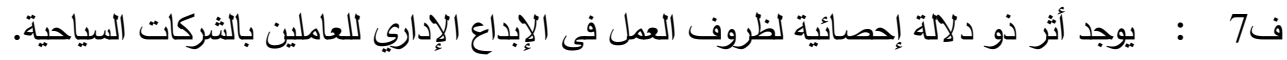


يوجد فروق الرئيسي الثاني ئقئي أفراد العينة لبيئة العمل حسب المتغيرات الديموغرافية التالية (النوع، الحالة الاجتماعية، السن، المستوى التعليمي، سنوات الخبرة). الفرض الرئيسي الثالث يوجد فروق معنوية في تقييم أفراد العينة للإبداع الإداري حسب المتغيرات الديموغرافية التالية (النوع، الحالة الاجتماعية، السن، المستوى التعليمي، سنوات الخبرة). منهج البحث

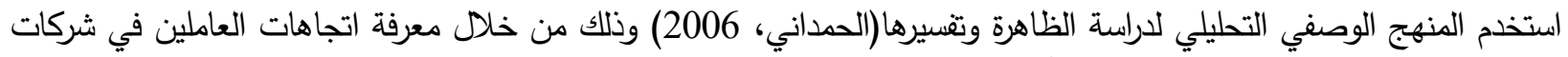

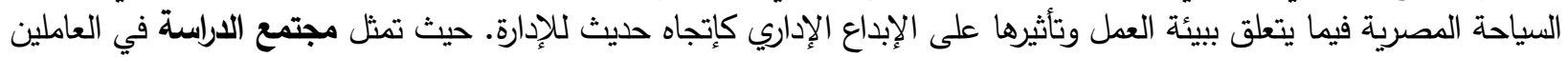

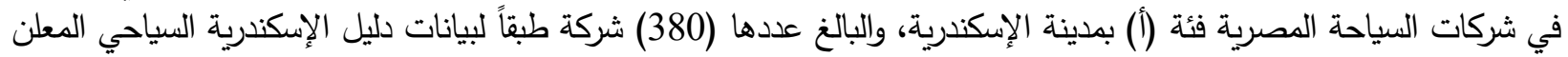

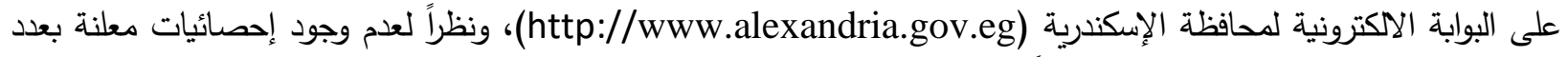

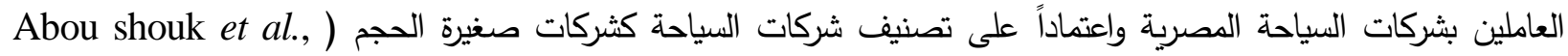

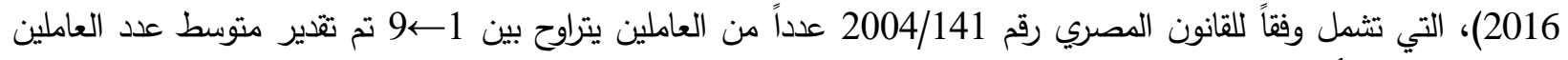

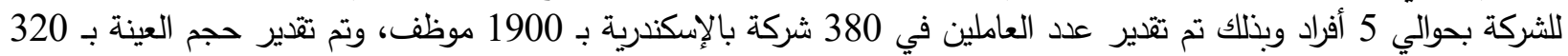
موظف تم اختيارهم بأسلوب العينة العشوائية البسيطة (Sekaran and Bougie, 2009)، وتم استرداد (276) استمارة صالحة للتحليل الإحصائي بمعدل استجابة 86.2\%، وسجلت العينة نسبة 15\% تقريباً من مجتمع الدراسة.

أداة البحث

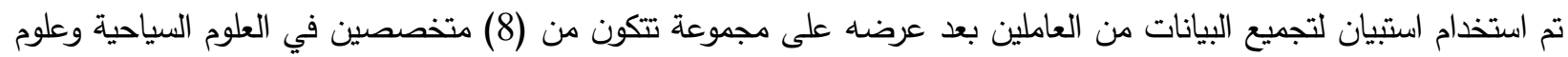

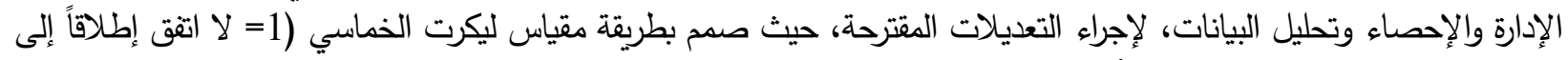
5= اتفق بثدة)، وقد انقسم إلى ثلاثثة أقتسام: الإحراء القسم الأول: يشمل البيانات الثخصية للمبحوثين (الجنس، الحالة الاجتماعية، السن، المستوى التعليمي وعدد سنوات الخبرة الوظيفية). القسم الثاني: يتكون من 35 عبارة لقياس بيئة العمل وعواملها داخل شركات السياحة (الهيكل التتظيمي، اللوائح والتعليمات،

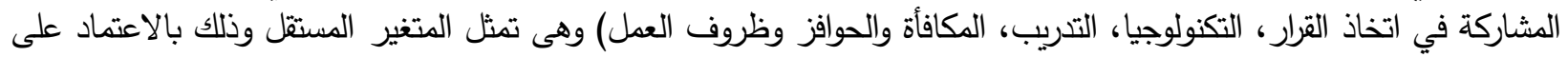

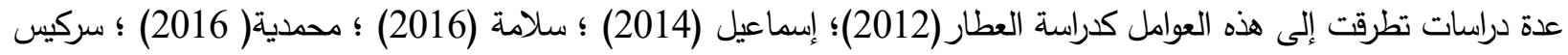

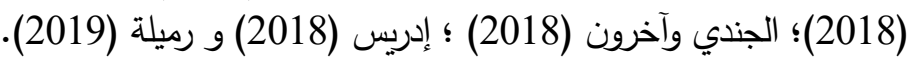

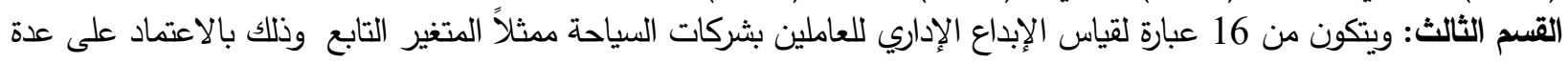

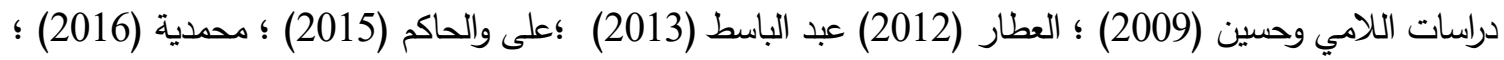

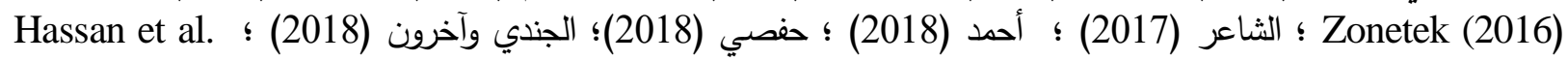
(2019) ورميلة (2018)

\section{صدق وثبات الاستبيان أولاً: صدق المقياس (الصدق البنائي)} جدول (1): يوضح علاقة الارتباط بين عوامل بيئة العمل والإبداع الإداري

\begin{tabular}{|c|c|c|c|c|c|c|c|c|c|}
\hline الإلإبداري & العمل & ظروف & المكافآت & التدريب & التكنولوجيا & التخاذ القراركة في & والتعليمات اللواتح & التنظيمي & متغيرات الدراسة \\
\hline & & & & & & & & 1 & الهيكل التتظيمي \\
\hline & & & & & & & 1 & $.276^{* *}$ & اللوائح والتعليمات \\
\hline & & & & & & 1 & $.343^{* *}$ & $.401^{* *}$ & المشاركة في اتخاذ القرار \\
\hline & & & & & 1 & $.397^{* *}$ & $.185^{* *}$ & $.450^{* * *}$ & التكنولوجيا \\
\hline & & & & 1 & $.656^{* *}$ & $.486^{* *}$ & $.171^{* *}$ & $.569^{* *}$ & التدريب \\
\hline & & & 1 & $.587^{* *}$ & $.452^{* *}$ & $.406^{* *}$ & $.211^{* *}$ & $.529^{* * *}$ & المكافآت والحوافز \\
\hline & & 1 & $.567^{* *}$ & $.558^{* *}$ & $.446^{* *}$ & $410 * *$ & $.216^{* *}$ & $.549^{* *}$ & ظروف العمل \\
\hline & 1 & $.775^{*}$ & $.785^{* *}$ & $.833^{* *}$ & $.739^{* * *}$ & $.656^{* *}$ & $.412^{* *}$ & $.750^{* * *}$ & بيئة العمل \\
\hline 1 & $.457^{* *}$ & $.447^{*}$ & $.323^{* *}$ & $.283^{* *}$ & $.372^{* *}$ & $.290^{* *}$ & $.223^{* *}$ & $.338^{* *}$ & الإبداع الإداري \\
\hline
\end{tabular}

** Correlation is significant at the 0.01 level (2-tailed). * Correlation is significant at the 0.05 level (2-tailed). 
يبين جدول (1) أن جميع معاملات الارتباط لمجالات وأبعاد الاستبيان دالة إحصائيا عند مستوى معنوي (0.05) وبذلك تعتبر جميع مجالات الاستبيان صادقة لما وضعت لقياسه.

ثانياً: ثبات الاستبيان

جدول (2): اختبار الصدق والثبات

\begin{tabular}{|c|c|c|c|}
\hline المصداقية & معامل كرونباخ ألفا لكل المتغيرات & معامل كرونباوخ ألفا & اسم المتغير \\
\hline \multirow{9}{*}{0.950} & \multirow{9}{*}{0.903} & .894 & الهيكل التتظيمي لثركة السياحة \\
\hline & & .907 & اللوائح والتعليمات المنظمة \\
\hline & & .898 & المشاركة في اتخاذ القرار \\
\hline & & .895 & التكنولوجيا \\
\hline & & .892 & 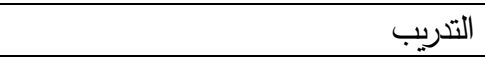 \\
\hline & & .896 & المكافآت والحوافز \\
\hline & & .892 & ظروف العمل \\
\hline & & .883 & معامل كرونباخ ألفا لكل عوامل بيئة العمل \\
\hline & & .896 & معامل كرونباخ ألفا للإبداع الإداري \\
\hline
\end{tabular}

يتضح جدول (2) أن قيمة معامل ألفا كرونباخ مرتفعة لكل عوامل ومجالات بيئة العمل (المتغير المستقل) حيث تتراوح بين (0,907 -

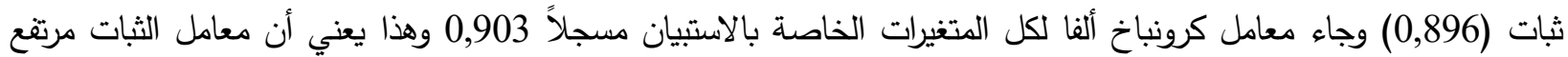

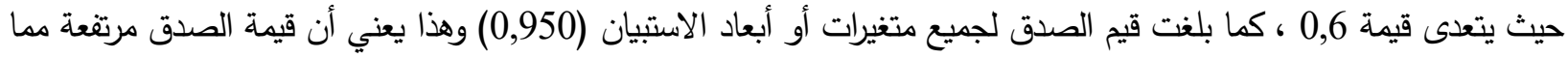
يؤكد صلاحية تحليل البيانات.

الأساليب الإحصائية المستخدمة تم استخدام عدة أساليب إحصائية لتحقيق أهداف الدراسة واختبار فروضها ببرنامج 24 المائية

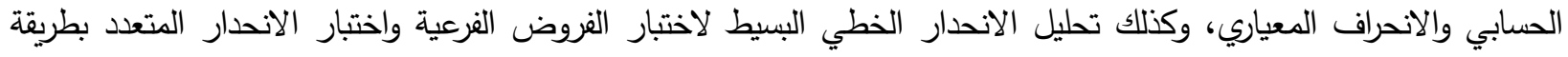

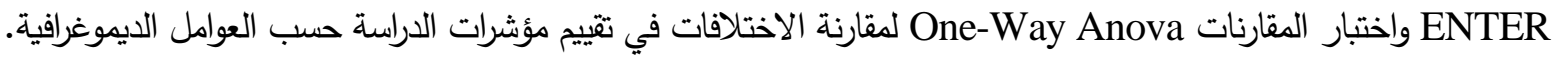

عرض نتائج الدراسة وتحليلها

جلول (3): الخصائص الليموغرافية لعينة البحث

\begin{tabular}{|c|c|c|c|c|c|}
\hline \multicolumn{2}{|c|}{ التكرارات من (276) } & \multirow{2}{*}{ الإيموغرافية } & \multicolumn{2}{|c|}{ التكرارات من (276) } & \multirow{2}{*}{ الخصيموغرافية } \\
\hline النسبة \% & العدد & & النسبة \% & العدد & \\
\hline \multicolumn{3}{|c|}{ النوع } & \multicolumn{3}{|c|}{ المستوى التعليمي } \\
\hline 46 & 127 & ذكر & 6.2 & 17 & الثانوية العامة \\
\hline 54 & 149 & أنثي & 87.7 & 242 & بكالوريوس \\
\hline \multicolumn{3}{|c|}{ الحالة الاجتماعية } & 5.8 & 16 & ماجستير أو دبلوم \\
\hline 54.7 & 151 & أعزب & 0.4 & 1 & دكتوراه \\
\hline 40.2 & 111 & متزوج & \multicolumn{3}{|c|}{ عدد سنوات الخبرة } \\
\hline 5.1 & 14 & أخري & 47.8 & 132 & 5 سنوات فاقُلّ \\
\hline \multicolumn{3}{|c|}{ السن } & 26.8 & 74 & $6-10$ \\
\hline 54.3 & 150 & اقل من 30 & 15.9 & 44 & 11-15 \\
\hline 30.1 & 83 & من 31-40 & 4.7 & 13 & $16-20$ \\
\hline 9.1 & 25 & من 41-50 & 2.9 & 8 & $21-25$ \\
\hline 6.5 & 18 & أكثر من 50 & 1.8 & 5 & أكثر من 25 \\
\hline
\end{tabular}

يوضح جدول (3) توزيع عينة البحث حسب الخصائص الديموغرافية حيث تبين أن الفئة الغالبة هي فئة الثباب مما يعكس ارتفاع نسبة من تقل خبرتهم الوظيفية عن 5 سنوات ، وأن نسبة 87,80\% كانت لحملة البكالوريوس مما يشكل عنصر قوة داخل بيئة 
التحليل الوصفي لمتغيرات الاراسة البحثية أولاً : بيئة العمل وعواملها المختلفة بالثركات السياحية

1. (الهيكل التنظيمي

جدول (4): التوزيعات النسبية والمتوسطات الحسابية والاحرافات المعيارية لأجوبة أفراد العينة عن العبارات المتطقة بالهيكل التنظيمي لثركة السياحة

\begin{tabular}{|c|c|c|c|c|c|c|c|c|c|}
\hline \multirow{3}{*}{ 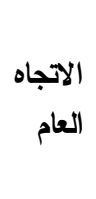 } & \multirow{3}{*}{ الترتيب } & \multirow{3}{*}{ المعياري } & \multirow{3}{*}{ الوسطب } & 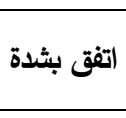 & اتفق & محايد & لا اتفق & بثدة اتفق & \multirow{3}{*}{ أسئلة خاصة بالهيكل التظيمي لثركة } \\
\hline & & & & 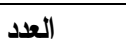 & 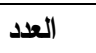 & 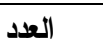 & 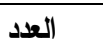 & 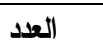 & \\
\hline & & & & النسبة & النسبة & النسبة & النسبة & النسبة & \\
\hline \multirow{2}{*}{ اتقق } & \multirow{2}{*}{2} & \multirow{2}{*}{.85227} & \multirow{2}{*}{3.7500} & 42 & 149 & 65 & 14 & 6 & \multirow{2}{*}{ ولشركة. مستويات وعناصر الهيكل التظظيمي } \\
\hline & & & & 15.2 & 54.0 & 23.6 & 5.1 & 2.2 & \\
\hline \multirow{2}{*}{ اتقق } & \multirow{2}{*}{3} & \multirow{2}{*}{.83573} & \multirow{2}{*}{3.7754} & 41 & 158 & 56 & 16 & 5 & \multirow{2}{*}{ وضالثركةح. الاختصاصات والصلاحيات للعاملين } \\
\hline & & & & 14.9 & 57.2 & 20.3 & 5.8 & 1.8 & \\
\hline اتقق & 4 & .87501 & 3.5942 & $\begin{array}{r}29 \\
10.5\end{array}$ & $\frac{141}{51.1}$ & $\begin{array}{r}79 \\
28.6\end{array}$ & $\begin{array}{r}19 \\
6.9\end{array}$ & $\begin{array}{r}8 \\
2.9\end{array}$ & مرونة الهيكل التنظيمي وانخفاض البيروقراطية. \\
\hline \multirow{2}{*}{ اتقق } & \multirow{2}{*}{5} & \multirow{2}{*}{.93273} & \multirow{2}{*}{3.5797} & 32 & 145 & 55 & 39 & 5 & \multirow{2}{*}{ وتاسبات مؤهلات العاملين بالثركة مع مهام } \\
\hline & & & & 11.6 & 52.5 & 19.9 & 14.1 & 1.8 & \\
\hline اتقق & 1 & .92396 & 3.8623 & $\begin{array}{r}71 \\
25.7\end{array}$ & $\frac{121}{43.8}$ & $\begin{array}{r}64 \\
23.2\end{array}$ & $\begin{array}{r}15 \\
5.4\end{array}$ & $\begin{array}{r}5 \\
1.8\end{array}$ & انتشار روح الفريق وتثجيع التكامل الوظيفي. \\
\hline اتنق & & .59378 & 3.7123 & & & & مياحة ) & 5 & الوسط الحسابي للعامل الأول ( الهيكل التظظي \\
\hline
\end{tabular}

يبين جدول (4) أن قيمة المتوسط الحسابي لعامل الهيكل التتظيمي كأحد عوامل بيئة العمل داخل شركات السياحة تبلغ 3,712 وبانحراف معياري (0,593) مما يعكس التقييم الإيجابي لتوفر عامل الهيكل التتظيمي ضمن بيئة العمل السياحية، حيث تم التوصل

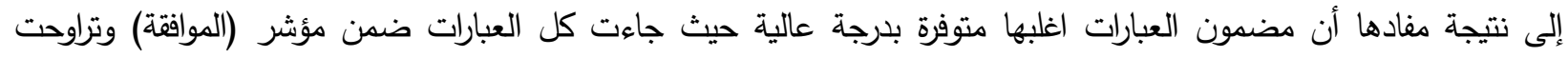
المتوسطات الحسابية لها بين (3,862 : 3,579). وبشكل عام يتضح أن مستوى أهمية الهيكل التنظيمي لثركات السياحة كان عالياً

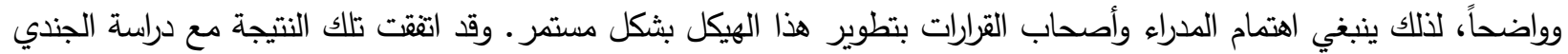

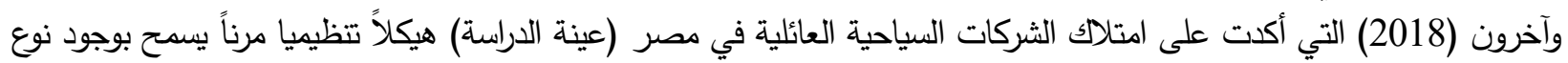
من الإبداع الإداري من خلا مرونته وسهولة تطوره لاستيعاب المتغيرات المستجدة.

2 2. اللوائح وإلتعليمات الخاصة بالثركة

جدول (5): التوزيعات النسبية والمتوسطات الحسابية والاحررفات المعيارية لأجوبة أفراد العينة عن العبارات المتطقة باللوائح والتطليمات لثركة السياحة

\begin{tabular}{|c|c|c|c|c|c|c|c|c|c|}
\hline \multirow{3}{*}{ 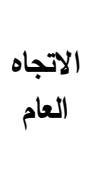 } & \multirow{3}{*}{ الترتيب } & \multirow{3}{*}{ المعياري } & \multirow{3}{*}{ الوسابي } & اتفق بثدة & اتفق & محايد & لا اتفق & لا لا اتفق & \multirow{3}{*}{ أسئلة خاصة باللوائح والتعليمات بشركة } \\
\hline & & & & 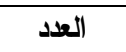 & العدد & 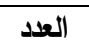 & العدد & العدد & \\
\hline & & & & النسبة & الننببة & النسبة & النسبة & النسبة & \\
\hline \multirow[b]{2}{*}{ اتقق } & \multirow{2}{*}{2} & \multirow{2}{*}{.87576} & \multirow{2}{*}{3.5870} & 36 & 121 & 93 & 21 & 5 & \multirow{2}{*}{ إنجاز الأعمال. الأظمة واللوائح بالثركة في تسهيل } \\
\hline & & & & 13.0 & 43.8 & 33.7 & 7.6 & 1.8 & \\
\hline \multirow{2}{*}{ محايد } & \multirow{2}{*}{4} & \multirow{2}{*}{1.03936} & \multirow{2}{*}{2.7246} & 10 & 61 & 78 & 97 & 30 & \multirow{2}{*}{ بالثرجد عدم وضؤرح في في بعض بنود التعليمات } \\
\hline & & & & 3.6 & 22.1 & 28.3 & 35.1 & 10.9 & \\
\hline اتقق & 3 & .89960 & 3.4058 & $\frac{22}{8.0}$ & $\begin{array}{c}116 \\
42.0\end{array}$ & $\begin{array}{c}98 \\
35.5\end{array}$ & $\begin{array}{c}32 \\
11.6\end{array}$ & $\begin{array}{c}8 \\
2.9\end{array}$ & تمتاز اللوائح والتعليمات بالمرونة. \\
\hline اتقق & 1 & .88931 & 3.6413 & $\begin{array}{c}34 \\
12.3\end{array}$ & $\begin{array}{l}147 \\
53.3\end{array}$ & $\begin{array}{c}62 \\
22.5\end{array}$ & $\begin{array}{c}28 \\
10.1\end{array}$ & $\begin{array}{c}5 \\
1.8\end{array}$ & تمتلك الثركة لوائح وأنظمة رقابية متتوعة. \\
\hline \multirow{2}{*}{ محايد } & \multirow{2}{*}{5} & \multirow{2}{*}{1.08376} & \multirow{2}{*}{2.5000} & 7 & 53 & 64 & 99 & 53 & \multirow{2}{*}{ والتطبيق اللقارات الإدارية بالثركة. فيتوى الالتزام } \\
\hline & & & & 2.5 & 19.2 & 23.2 & 35.9 & 19.2 & \\
\hline محايد & \multicolumn{2}{|c|}{.45535} & 3.1717 & \multicolumn{6}{|c|}{ الوسط الحسابي للعامل الثاني (اللوائح والتعليمات المنظمة بشركات السياحة) } \\
\hline
\end{tabular}

يثير جدول (5) أن قيمة المتوسط الحسابي لعامل اللوائح والأنظمة تبلغ (3.171) وبانحراف معياري قدره (0.455)، إذ تراوحت المتوسطات الحسابية لهذا العامل بين (2.500:3.641). وبشكل عام تبين أن مستوى أهمية اللوائح والأنظمة والتعليمات في

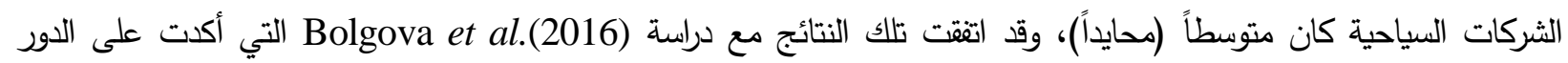


الفاعل لأساليب المتابعة الإدارية والأنظمة الرقابية بالثركات السياحية كداعم رئيسي لعمليات الإبداع. بينما اختلفت مع دراسة

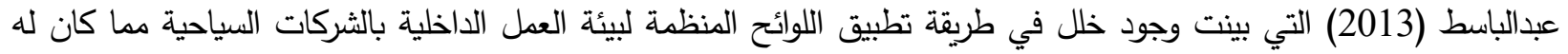
تأثير محدود في عمليات الإبداع الإداري وعدم رضاء العاملين عن أنظمة وإجراءات العمل الداخلية.

3. 3. المشاركة في اتخاذ القرار

جدول (6): التوزيعات النسبية والمتوسطات الحسابية والانحرافات المعيارية لأجوبة أفراد العينة عن العبارات المتعلقة بالمشاركة في اتخاذ القرار بشركات السياحة

\begin{tabular}{|c|c|c|c|c|c|c|c|c|c|}
\hline \multirow{3}{*}{ 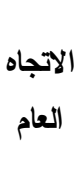 } & \multirow{3}{*}{ الترتيب } & \multirow{3}{*}{ 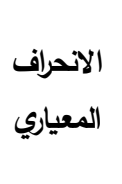 } & \multirow{3}{*}{ الوسابي } & اتفق بثدة & اتقق & محايد & لا اتفق & لا لا بثقة & \multirow{3}{*}{ فئلة اتخاذة القرار } \\
\hline & & & & العلد & العدد & العدد & العدد & العدد & \\
\hline & & & & النسبة & النسبة & النسبة & النسبة & النسبة & \\
\hline \multirow{2}{*}{ اتقق } & \multirow{2}{*}{2} & \multirow{2}{*}{1.02637} & \multirow{2}{*}{3.4312} & 32 & 120 & 73 & 37 & 14 & \multirow{2}{*}{ 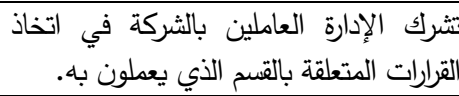 } \\
\hline & & & & 11.6 & 43.5 & 26.4 & 13.4 & 5.1 & \\
\hline \multirow[b]{2}{*}{ اتقق } & \multirow{2}{*}{1} & \multirow[b]{2}{*}{.90913} & \multirow{2}{*}{3.6159} & 35 & 139 & 70 & 25 & 7 & \multirow{2}{*}{ تحترم الإدارة آراء وقرارات المرؤوسين. } \\
\hline & & & & 12.7 & 50.4 & 25.4 & 9.1 & 2.5 & \\
\hline \multirow{2}{*}{ محايد } & \multirow{2}{*}{4} & \multirow{2}{*}{.95083} & \multirow{2}{*}{3.2717} & 20 & 100 & 103 & 41 & 12 & \multirow{2}{*}{ تشثل ظاهري. الإدارة المرؤوسين في اتخاذ القرارات } \\
\hline & & & & 7.2 & 36.2 & 37.3 & 14.9 & 4.3 & \\
\hline \multirow{2}{*}{ اتقق } & \multirow{2}{*}{3} & \multirow{2}{*}{.95795} & \multirow{2}{*}{3.4022} & 23 & 125 & 78 & 40 & 10 & \multirow{2}{*}{ تقوافع وأهداف شخصية العاملين بالشركة كأثخاص لهج } \\
\hline & & & & 8.3 & 45.3 & 28.3 & 14.5 & 3.6 & \\
\hline \multirow{2}{*}{ محايد } & \multirow[b]{2}{*}{5} & \multirow[b]{2}{*}{1.01053} & \multirow[b]{2}{*}{3.0254} & 17 & 76 & 97 & 69 & 17 & \multirow{2}{*}{ والمشاركة مع الآخرارين. الإدارية بعيداً عن التتسيق } \\
\hline & & & & 6.2 & 27.5 & 35.1 & 25.0 & 6.2 & \\
\hline محايد & \multicolumn{2}{|c|}{.53588} & 3.3493 & \multicolumn{6}{|c|}{ الوسط الحسابي للعامل الثالث (المشاركة في اتخاذ القرار بشركات السياحة) } \\
\hline
\end{tabular}

يشير جدول (6) إلى أن قيمة المتوسط الحسابي لعامل المشاركة في اتخاذ القرار تبلغ (3.349) وبانحراف معياري قدره (0.535).

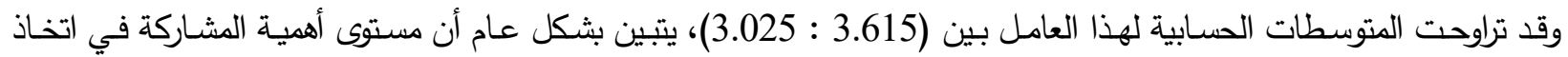

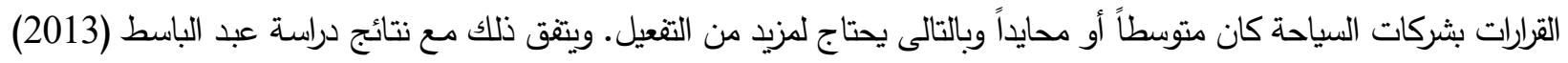
التى أثثتت أن عنصر الرؤية المشتركة لـه التأثير الأكبر على الإبداع الإدارى بالثركات السياحية ودراستة الجندي وآخرون (2018)

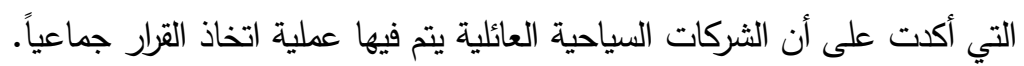

4.

جدول (7): التوزيعات النسبية والمتوسطات الحسابية والانحرافات المعيارية لأجوبة أفراد العينة عن العبارات المتطقة بالتكنولوجيا بشركات السياحة

\begin{tabular}{|l|l|l|l|c|c|c|c|c|}
\hline & & & & \\
\end{tabular}

يبين جدول (7) أن قيمـة المتوسط الحسابي لعامل التكنولوجيا بشركات السياحة يبلغ (3.662) والانحراف المعياري (0.745) مما

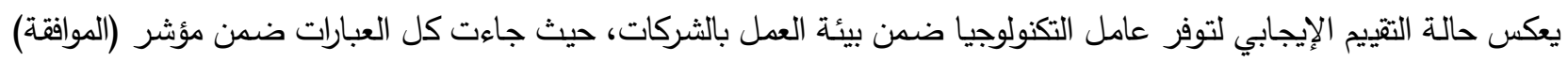
ويؤكد على أهمية التكنولوجيا باعتباره معياراً لقياس مدى التقدم الإداري للثركات في مجتمع يقوم على المنافسة العالمية واستخدام 


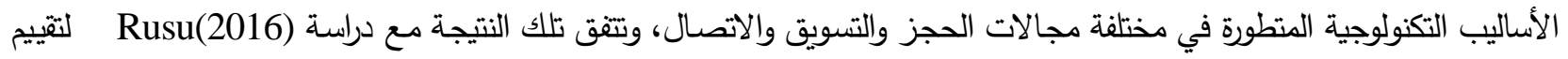

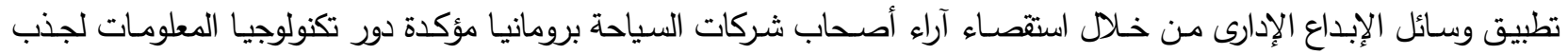
العملاء لتحسين الخدمات السياحية المقدمة وكذلك دراسة السعيد (2018). 5

جدول (8): التوزيعات النسبية والمتوسطات الحسابية والاحررفات المعيارية لأجوبة أفراد العينة عن العبارات المتعلقة بعامل التدريب بشركات السياحة

\begin{tabular}{|c|c|c|c|c|c|c|c|c|c|}
\hline \multirow{3}{*}{ 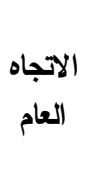 } & \multirow{3}{*}{ الترتيب } & \multirow{3}{*}{ ال الانحراف } & \multirow{3}{*}{ الحسابي } & بثدة & اتفق & محايد & $\begin{array}{c} \\
\text { اتفق } \\
\end{array}$ & لا اتفق بشدة & \multirow{3}{*}{ أسئلة خاصة بالتدريب } \\
\hline & & & & العلد & العدد & العدد & العدد & العدد & \\
\hline & & & & الننبة & الننبة & الننبة & الننبة & النسبة & \\
\hline \multirow{2}{*}{ اتقق } & \multirow{2}{*}{3} & \multirow{2}{*}{.95584} & \multirow{2}{*}{3.5797} & 35 & 137 & 67 & 27 & 10 & \multirow{2}{*}{ تهياحتية الشركة بإثراك العاملين في دورات تريبية } \\
\hline & & & & 12.7 & 49.6 & 24.3 & 9.8 & 3.6 & \\
\hline \multirow{2}{*}{ اتتق } & \multirow{2}{*}{1} & \multirow{2}{*}{.90091} & \multirow{2}{*}{3.6449} & 35 & 144 & 70 & 18 & 9 & \multirow{2}{*}{ تطوير برامجات التدريب التي تتبناها الثركة إلى } \\
\hline & & & & 12.7 & 52.2 & 25.4 & 6.5 & 3.3 & \\
\hline \multirow{2}{*}{ اتقق } & \multirow{2}{*}{2} & \multirow{2}{*}{.98180} & \multirow{2}{*}{3.5833} & 41 & 126 & 73 & 25 & 11 & \multirow{2}{*}{ 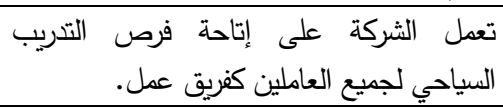 } \\
\hline & & & & 14.9 & 45.7 & 26.4 & 9.1 & 4.0 & \\
\hline \multirow{2}{*}{ اتتق } & \multirow{2}{*}{5} & \multirow{2}{*}{.92430} & \multirow{2}{*}{3.5145} & 30 & 126 & 85 & 26 & 9 & \multirow{2}{*}{ تهالمسار الثنريبي. بربط المسار الوظيفي للعاملين } \\
\hline & & & & 10.9 & 45.7 & 30.8 & 9.4 & 3.3 & \\
\hline \multirow{2}{*}{ اتقق } & \multirow[b]{2}{*}{4} & \multirow{2}{*}{87503} & \multirow{2}{*}{3.5399} & 25 & 137 & 84 & 22 & 8 & \multirow{2}{*}{ كوادر بشرية مبدعة. التُريب خيارً استراتيجياً لإعداد } \\
\hline & & & & 9.1 & 49.6 & 30.4 & 8.0 & 2.9 & \\
\hline اتقق & & 439 & 3.5725 & & & يايحة & & المس (ال) & الوسط الحسابي اللع \\
\hline
\end{tabular}

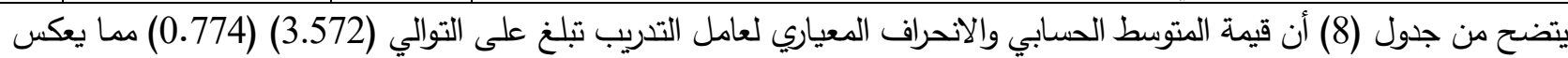

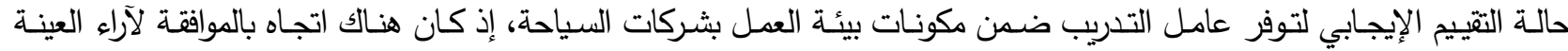

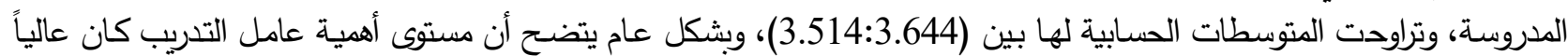

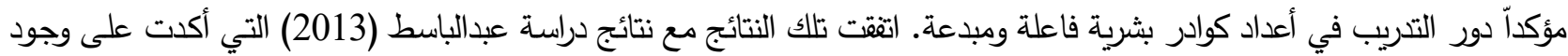
خطة للتدريب للعاملين والمدراء بالثركة القابضة للسياحة والفنادق والثركات التابعة لها لتحسين وتطوير معرفتهم بماهية الإبداع الإداري.

6. المكافآت والحوافز

جدول (9): التوزيعات النسبية والمتوسطات الحسابية والانحرافات المعيارية لأجوبة أفراد العينة عن العبارات المتعقة بالمكافآت والحوافز بشركات السياحة

\begin{tabular}{|c|c|c|c|c|c|c|c|c|c|}
\hline \multirow{3}{*}{ 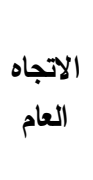 } & \multirow{3}{*}{ الترتيب } & \multirow{3}{*}{ 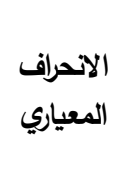 } & \multirow{3}{*}{ الحسابي } & بثدة & اتفق & محايد & لا اتفق & لا لا اتفق & \multirow{3}{*}{ أسئلة خاصة بالمكافآت والحوافز } \\
\hline & & & & العلد - العل & العدد العد & العلد - العل & العدد - العد & العدد - العد & \\
\hline & & & & النسبة & النسبة & النسبة & النسبة & النسبة & \\
\hline \multirow[b]{2}{*}{ أتقق } & \multirow{2}{*}{1} & \multirow[b]{2}{*}{99630} & \multirow{2}{*}{3.5109} & 36 & 124 & 72 & 33 & 11 & \multirow{2}{*}{ الأداء الوظيفي. } \\
\hline & & & & 13.0 & 44.9 & 26.1 & 12.0 & 4.0 & \\
\hline \multirow{2}{*}{ محايد } & \multirow{2}{*}{3} & \multirow{2}{*}{1.02127} & \multirow{2}{*}{3.3080} & 30 & 96 & 92 & 45 & 13 & \multirow{2}{*}{ والموضيز نظام. الدكافآت والحوافز بالثركة بالغعالية } \\
\hline & & & & 10.9 & 34.8 & 33.3 & 16.3 & 4.7 & \\
\hline \multirow{2}{*}{ محايد } & & \multirow{2}{*}{1.08410} & \multirow{2}{*}{3.3551} & 31 & 114 & 74 & 36 & 21 & \multirow{2}{*}{ تكاحئ الثركة العاملين في حالة تقديم أفكار } \\
\hline & & & & 11.2 & 41.3 & 26.8 & 13.0 & 7.6 & \\
\hline \multirow{2}{*}{ محايد } & & \multirow{2}{*}{1.19211} & \multirow{2}{*}{3.2899} & 33 & 95 & 75 & 55 & 18 & \multirow{2}{*}{ 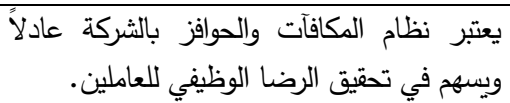 } \\
\hline & & & & 12.0 & 34.4 & 27.2 & 19.9 & .065 & \\
\hline \multirow{2}{*}{ محايد } & & \multirow{2}{*}{1.05643} & \multirow{2}{*}{3.0181} & 19 & 77 & 92 & 66 & 22 & \multirow{2}{*}{ يحملاءم الذخل المؤهل) في الثركات العناظرة (الذين } \\
\hline & & & & 6.9 & 27.9 & 33.3 & 23.9 & 8.0 & \\
\hline محايد & & 3 & 2964 & & & & & & الوسط الحسابي للعامل الد \\
\hline
\end{tabular}

يوضح جدول (9) أن قيمة المتوسط الحسابي لعامل المكافآت والحوافز بلغت (3.296) والانحراف المعياري (0.848). وبشكل عام يتضح أن مستوى توفر عامل الحوافز والمكافآت كان متوسطاً أو محايداً رغم أن للحوافز دوراً كبيراً في تدعيم القدرات الإبداعية لدى الدى 
العاملين مما يعكس وجود تحفظات خاصة بعينة الدراسة ترتبط بنظم المكافأة المعنوية والمادية بالثركات وكيفية ربطها بالأداء الوظيفي. وظهرت النتائج فى نفس اتجاه نتائج دراسة (2016 ) Zonetek ودراسة حفصى (2018).

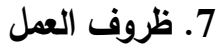

جدول (10): التوزيعات النسبية والمتوسطات الحسابية والاحررفات المعيارية لأجوبة أفراد العينة عن العبارات المتعقة بظروف العمل بثركات السياحة

\begin{tabular}{|c|c|c|c|c|c|c|c|c|c|}
\hline \multirow{3}{*}{ ال الاتجاه } & \multirow{3}{*}{ الترتيب } & \multirow{3}{*}{ 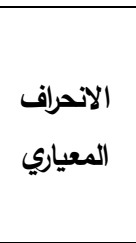 } & \multirow{3}{*}{ العسابي } & 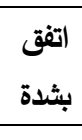 & اتفق & محايد & لا اتفق & لا لا بقدة & \multirow{3}{*}{ أسئلة خاصة بظروف العمل } \\
\hline & & & & العلد & العدد & العلد & العدد & العدد & \\
\hline & & & & النسبة & النسبة & النسبة & النسبة & النسبة & \\
\hline \multirow{2}{*}{ اتقق } & \multirow{2}{*}{5} & \multirow{2}{*}{0.87008} & \multirow{2}{*}{3.5543} & 31 & 125 & 91 & 24 & 5 & \multirow{2}{*}{ تلعقمل الثركة بتوفير كافة التسهيلات } \\
\hline & & & & 11.2 & 45.3 & 33.0 & 8.7 & 1.8 & \\
\hline \multirow[b]{2}{*}{ اتقق } & \multirow{2}{*}{4} & \multirow{2}{*}{0.91614} & \multirow{2}{*}{3.6232} & 41 & 124 & 85 & 18 & 8 & \multirow{2}{*}{ بشعر العاملون بالشركة بالارتياح والألفة } \\
\hline & & & & 14.9 & 44.9 & 30.8 & 6.5 & 2.9 & \\
\hline \multirow[b]{2}{*}{ اتقق } & \multirow[b]{2}{*}{1} & \multirow[b]{2}{*}{1.97367} & \multirow{2}{*}{3.7935} & 40 & 139 & 75 & 14 & 8 & \multirow{2}{*}{ 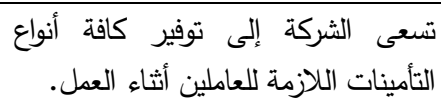 } \\
\hline & & & & 14.5 & 50.4 & 27.2 & 5.1 & 2.9 & \\
\hline \multirow[b]{2}{*}{ اتقق } & \multirow[b]{2}{*}{3} & \multirow{2}{*}{0.92482} & \multirow{2}{*}{3.6884} & 134 & 45 & 72 & 16 & 9 & \multirow{2}{*}{ تلوفر الثركة ظافروف الأمن والسلامة } \\
\hline & & & & 48.6 & 16.3 & 26.1 & 5.8 & 3.3 & \\
\hline \multirow[b]{2}{*}{ اتقق } & \multirow[b]{2}{*}{2} & \multirow[b]{2}{*}{.89692} & \multirow[b]{2}{*}{3.7935} & 56 & 133 & 67 & 14 & 6 & \multirow{2}{*}{ توفر الثركة أثاثاً مكتبياً وديكوراً مناسباً } \\
\hline & & & & 20.3 & 48.2 & 24.3 & 5.1 & 2.2 & \\
\hline اتقق & \multicolumn{2}{|c|}{.78831} & 3.6906 & \multicolumn{6}{|c|}{ الوسط الحسابي للعامل السابع (ظروف العمل بشركات السياحة) } \\
\hline
\end{tabular}

يوضح جدول (10) أن قيمة المتوسط الحسابي لعامل ظروف العمل والانحراف المعياري سجلت (3.690) و (0.788) على التوالي

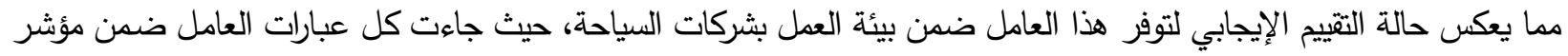

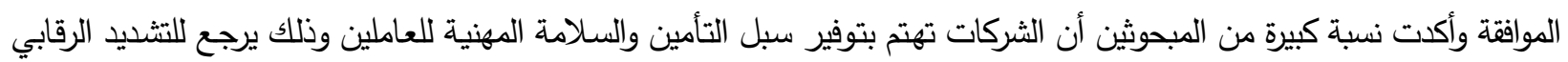

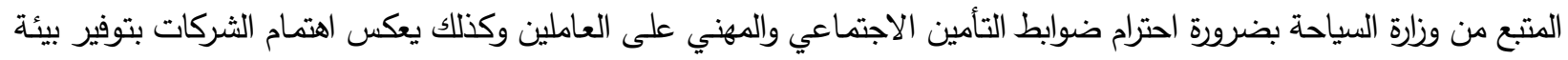

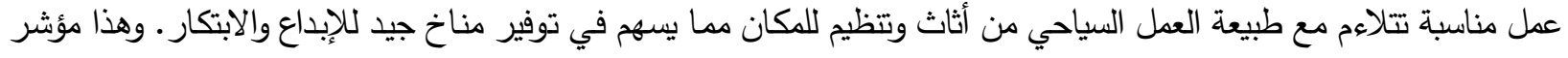

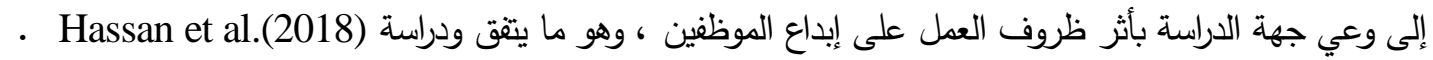

ترتيب متوسطات العوامل المتعلقة ببيئة العمل بشركات السياحة

جدول (11): ترتيب متوسطات عوامل بيئة العمل حسب عينة الدراسة

\begin{tabular}{|c|c|c|c|}
\hline الترتيب & الالاعراف & الوسط الحسابي & اسم المتغير \\
\hline 1 & .59378 & 3.7123 & الهيكل التتظيمي لشركة السياحة \\
\hline 7 & .45535 & 3.1717 & اللوائح والتعليمات المنظمة \\
\hline 5 & .53588 & 3.3493 & المشاركة في اتخاذ القرار \\
\hline 3 & .74572 & 3.6623 & التكنولوجيا \\
\hline 4 & .77439 & 3.5725 & التدريب \\
\hline 6 & .84843 & 3.2964 & المكافآت والحوافز \\
\hline 2 & .78831 & 3.6906 & ظروف العمل \\
\hline \multicolumn{2}{|c|}{.49384} & 3.4936 & بيئة العمل \\
\hline
\end{tabular}

يتضح من جدول (11) أن المتوسط الحسابي لعوامل بيئة العمل تراوح بين 3.17 إلى 3.71، مما يدل على أهمية امتلاك الشركات السياحية لهيكل تتظيمي متكامل مرن وبسيط لتشجيع الإبداع بين العاملين. 
ثانياً: الإبداع الإداري للعاملين بالثركات السياحية

جدول (12): التوزيعات النسبية والمتوسطات الحسابية والانحرافات المعيارية لأجوبة أفراد العينة عن عبارات الإبداع الإداري للعاملين بثركات السياحة

\begin{tabular}{|c|c|c|c|c|c|c|c|c|c|}
\hline \multirow{3}{*}{ الالاماه } & \multirow{3}{*}{ الترتيب } & \multirow{3}{*}{ الانحراف } & \multirow{3}{*}{ الوسطابي } & الثقدة & اتفق & محايد & 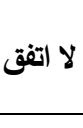 & لا بثق اتفق & \multirow{3}{*}{ أسئلة خاصة بالإبداع الإداري } \\
\hline & & & & العدد & العدد & العدد & العدد & العدد & \\
\hline & & & & النسبة & النسبة & النسبة & النسبة & النسبة & \\
\hline \multirow{2}{*}{ اتقق } & \multirow{2}{*}{13} & \multirow{2}{*}{.87438} & \multirow{2}{*}{3.7464} & 46 & 141 & 68 & 15 & 6 & \multirow{2}{*}{ أعبر دائماً عن مقترحاتي الجديدة بثقة. } \\
\hline & & & & 16.7 & 51.1 & 24.6 & 5.4 & 2.2 & \\
\hline \multirow{2}{*}{ اتقق } & \multirow{2}{*}{12} & \multirow{2}{*}{.86449} & \multirow{2}{*}{3.7790} & 49 & 142 & 65 & 15 & 5 & \multirow{2}{*}{ 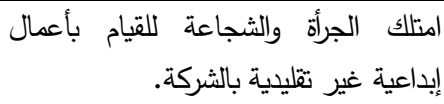 } \\
\hline & & & & 17.8 & 51.4 & 23.6 & 5.4 & 1.8 & \\
\hline \multirow{2}{*}{ اتقق } & \multirow{2}{*}{15} & \multirow{2}{*}{.91444} & \multirow{2}{*}{3.6051} & 40 & 123 & 83 & 24 & 6 & \multirow{2}{*}{ تاتخذ قرارات التغيير والتحديث بناء على } \\
\hline & & & & 14.5 & 44.6 & 30.1 & 8.7 & 2.2 & \\
\hline \multirow{2}{*}{ اتقق } & \multirow{2}{*}{2} & \multirow{2}{*}{.82863} & \multirow{2}{*}{4.0254} & 81 & 136 & 46 & 11 & 2 & \multirow{2}{*}{ أرغب في العمل ضمن فريق تسوده روح } \\
\hline & & & & 29.3 & 49.3 & 16.7 & 4.0 & .7 & \\
\hline \multirow{2}{*}{ اتقق } & \multirow{2}{*}{11} & \multirow{2}{*}{.85324} & \multirow{2}{*}{3.8116} & 51 & 143 & 68 & 7 & 7 & \multirow{2}{*}{ أقداء مقترحات وأساليب جليدة تساعد علي } \\
\hline & & & & 18.5 & 51.8 & 24.6 & 2.5 & 2.5 & \\
\hline \multirow{2}{*}{ محايد } & \multirow{2}{*}{16} & \multirow{2}{*}{1.13665} & & 43 & 101 & 72 & 39 & 21 & أشعر بالملل من تكرار الإجراءات المتبعة \\
\hline & & & 3.3841 & 15.6 & 36.6 & 26.1 & 14.1 & 7.6 & في إنجاز مهام العمل. \\
\hline & & & & 64 & 158 & 44 & 6 & 4 & أحرص على الاستقادة من الانتقادات \\
\hline اتقق & 3 & .78147 & 3.9855 & 23.2 & 57.2 & 15. & 2.2 & 1 & والملاحظات الموجهة لي. \\
\hline اتقق & 5 & .73798 & 3.9710 & 54 & 173 & 40 & 5 & 4 & ألتعاون مع أصحاب الأفكار والمقترحات \\
\hline & 7 & 69853 & 30457 & 45 & 182 & 42 & 3 & 4 & ركفاعة توأ \\
\hline اتقق & 7 & .69853 & 3.9451 & 16.3 & 65.9 & 15.2 & 1.1 & 1.4 & اججر الا عمل بحقاءه وباسلوب \\
\hline التقت & 10 & 73544 & 38913 & 46 & 166 & 55 & 6 & 3 & أحرص على إحداث تغييرات في أساليب \\
\hline السق & 10 & .13544 & 3.8913 & 16.7 & 60.1 & 19.9 & 2.2 & 1.1 & العمل المتبعة بين فترة وأخرى. \\
\hline
\end{tabular}

تابع جدول (12): التوزيعات النسبية والمتوسطات الحسابية والانحرافات المعيارية لأجوبة أفراد العينة عن عبارات الإبداع الإداري للعاملين بشركات السياحة

\begin{tabular}{|c|c|c|c|c|c|c|c|c|c|}
\hline \multirow[t]{2}{*}{ اتقق } & \multirow[t]{2}{*}{9} & \multirow[t]{2}{*}{.72129} & \multirow[t]{2}{*}{3.9420} & 48 & 177 & 41 & 7 & 3 & \multirow{2}{*}{ العلاقات القدرة على التفكير السريع وإدراك } \\
\hline & & & & 17.4 & 64.1 & 14.9 & 2.5 & 1.1 & \\
\hline \multirow{2}{*}{ اتقق } & \multirow[t]{2}{*}{6} & \multirow[t]{2}{*}{.71530} & \multirow[t]{2}{*}{3.9674} & 58 & 158 & 54 & 5 & 1 & \multirow{2}{*}{ امتلك القدرة على إدارة الحوار والمناقثات. } \\
\hline & & & & 21.0 & 57.2 & 19.6 & 1.8 & .4 & \\
\hline \multirow{2}{*}{ اتفق } & \multirow[t]{2}{*}{1} & \multirow[t]{2}{*}{2.47286} & \multirow[t]{2}{*}{4.0362} & 52 & 152 & 65 & 2 & 4 & \multirow{2}{*}{ لدى القدرة على تقديم أفكار غير تقليدية } \\
\hline & & & & 18.8 & 55.1 & 23.6 & .7 & 1.4 & \\
\hline \multirow{2}{*}{ اتفق } & \multirow[t]{2}{*}{14} & \multirow[t]{2}{*}{.75993} & \multirow[t]{2}{*}{3.7101} & 32 & 149 & 80 & 13 & 2 & \multirow{2}{*}{ قامتلك رؤية لاكتثاف المشكلات والتنتؤ بها } \\
\hline & & & & 11.6 & 54.0 & 29.0 & 4.7 & .7 & \\
\hline \multirow{2}{*}{ اتقق } & \multirow[t]{2}{*}{7} & \multirow[t]{2}{*}{.65308} & \multirow[t]{2}{*}{3.9493} & 47 & 172 & 54 & 2 & 1 & \multirow{2}{*}{ للدى القدرة على تقديم حلول جديدة وسريعة } \\
\hline & & & & 17.0 & 62.3 & 19.6 & 0.7 & .4 & \\
\hline \multirow{2}{*}{ اتفق } & \multirow[t]{2}{*}{4} & \multirow[t]{2}{*}{.74057} & \multirow[t]{2}{*}{3.9746} & 58 & 164 & 46 & 5 & 3 & \multirow{2}{*}{ أحاول الابتعاد عن تقليد الآخرين في حل } \\
\hline & & & & 21.0 & 59.4 & 16.7 & 1.8 & 1.1 & \\
\hline اتقق & \multicolumn{2}{|c|}{.46262} & 3.8925 & \multicolumn{6}{|c|}{ الوسط الحسابي للإبداع الإداري للعاملين بشركات السياحة } \\
\hline
\end{tabular}

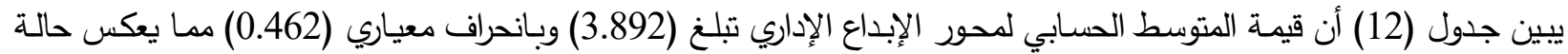

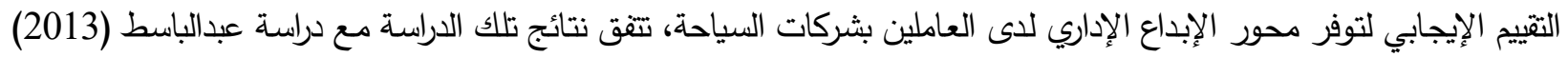

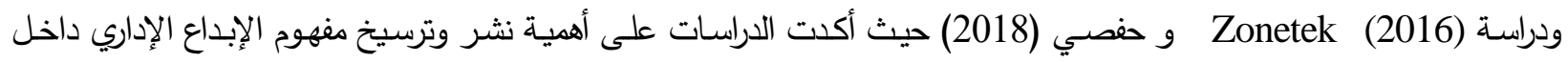
الثركات السياحية للإسهام في ابتكار الحلول والمقترحات التي تئدى إلى النهوض بهذه الثركات ، بينما تختلف هذه النتيجة ونتائج 
دراسة (2018) مassan et al. التي توصلت إلى عدم وصدول مستوى الإبداع لدى أفراد العينة دن العاملين إلى المستويات المرتفعة مما يعكس ضعف تبنى شركات السياحة الصغرى في مصر عناصر الإبداع الإداري. اختبار فروض الدراسة الفرض الرئيسي الأول يوجد أثر ذو دلالة إحصائية لعوامل بيئة العمل (الهيكل التنظيمي، اللوائح والأنظمة، التدريب، التكنولوجيا، المشاركة في اتخاذ

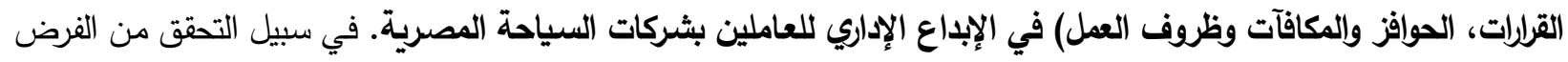
ثم إجراء اختبار الانحدار المتعدد بطريقة Enter للدلالمة على تأثير المتغيرات (العوامل) المستقلة لبيئة العمل (الهيكل التتظيهي، اللوائح والأنظمة، التدريب، التكنولوجيا، المشاركة في اتخاذ القرار ، الحوافز وظروف العمل) على المتغير التابع (الإبداع الإداري). جدول (13): تحليل الاتحدار المتعدد لتأثير عوامل بيئة العمل في الإبداع الإداري

\begin{tabular}{|c|c|c|c|c|c|}
\hline \multicolumn{6}{|c|}{$\mathrm{R}^{2}=0.245 ; \mathrm{SEE}=0.40199 ; \mathrm{F}=13.744 ;$ ANOVA's Test sig. $=0.000$} \\
\hline المعنوية & 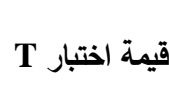 & معاملات الاحدار & الخطأ المعياري & معاملات الانحار & 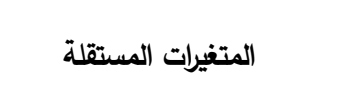 \\
\hline .000 & 10.192 & & .217 & 2.209 & 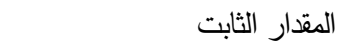 \\
\hline .288 & 1.065 & .075 & .055 & .058 & الهيكل التنظيمي لشركة السياحة \\
\hline .139 & 1.483 & .084 & .058 & .086 & 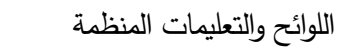 \\
\hline .295 & 1.050 & .067 & .055 & .058 & المشاركة في اتخاذ القرار \\
\hline${ }^{* * * *} .001$ & 3.483 & .246 & .044 & .153 & 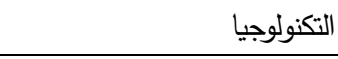 \\
\hline *.037 & 2.101 & .175 & .050 & .104 & التدريب \\
\hline .497 & .681 & .048 & .039 & .026 & المكافآت والحوافز \\
\hline${ }^{* * *} .000$ & 4.529 & .320 & .041 & 188 & ظروف العمل \\
\hline
\end{tabular}

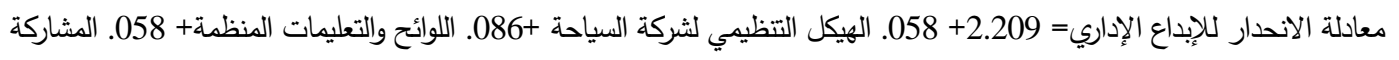

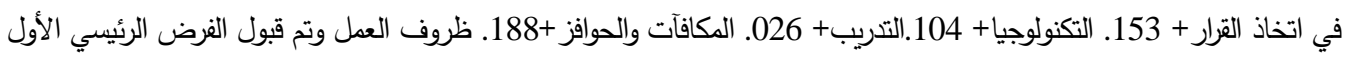
${ }^{*} \mathrm{p}<.05 . * * \mathrm{p}<.01 . * * * \mathrm{p}<.001$

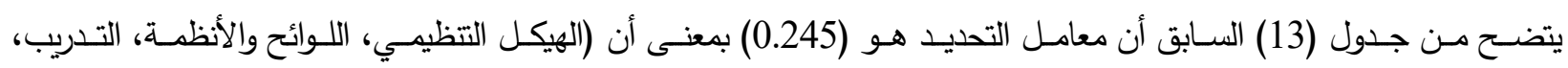

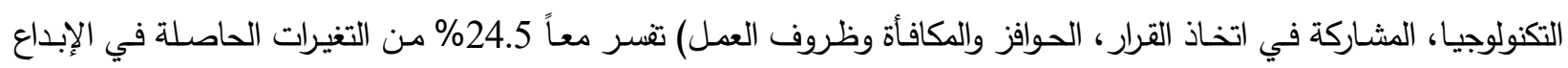

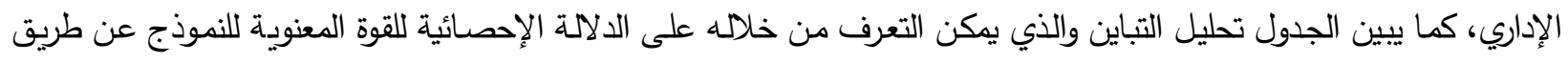

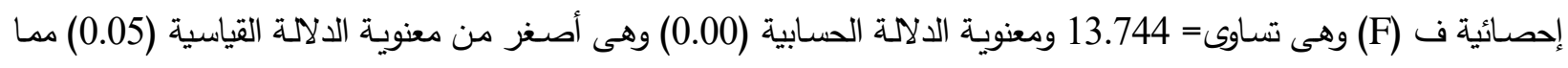
يؤكد الدلالة الإحصائية لنموذج الاتحدار من الناحية الإحصائية بمعنى أن النموذج ذو دلالمة. كما يشير الجدول إلى أن قيمة تأثير

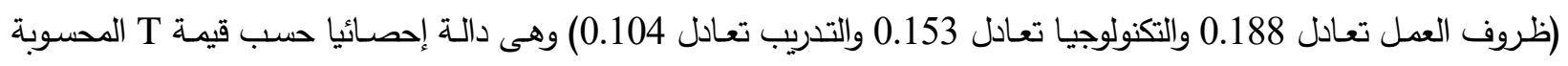

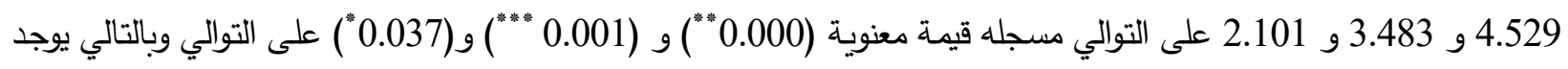
أثر ذا دلالة إحصائية لعوامل بيئة العمل من حيث (ظروف العمل، التكنولوجيا والتدريب) في الإبداع الإداري للعاملين، بينما (الهيكل

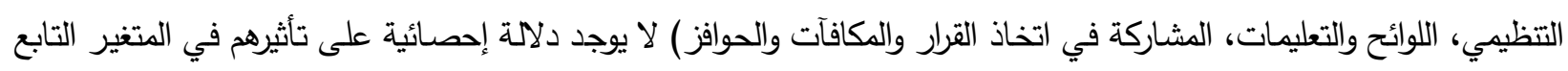

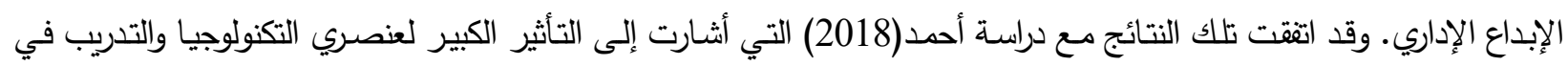
الإبداع الإداري للعاملين، ودراسة حفصي (2018) التي أشارت إلى دور القيادة الإدارية في تثجيع الإبداع الإداري وذلك من خلاد تبنيها لوسائل تكنولوجية منطورة ونظام حوافز عادل ومشاركة للعاملين في صنع القرارات كعوامل أساسية لبيئة العمل. 


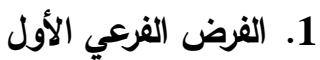

يوجد أثر ذو دلالة إحصائية للهيكل التظيمي في الإبداع الإداري للعاملين بالشركات السياحية. جدول (14): تحليل الاحدار الخطي البسيط لأثر الهيكل التنظيمي للثركة في الإبداع الإداري للعاملين لإنين

\begin{tabular}{|c|c|c|c|c|c|}
\hline \multicolumn{6}{|c|}{$\mathrm{R}^{2}=0.111 ; \mathrm{SEE}=0.43627 ; \mathrm{F}=35.225 ;$ ANOVA's Test sig. $=0.000$} \\
\hline المغوية & Tيمة اختبار T & 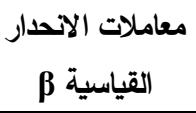 & الخطأ المعياري & معاملات الانحدار & المتغيرات المستقلة \\
\hline .000 & 17.300 & & .167 & 2.882 & 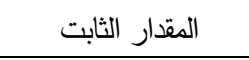 \\
\hline$* * * * 000$ & 5.935 & .338 & .044 & .263 & الهيكل التظيمي للثركة \\
\hline
\end{tabular}

*p < .05. **p <. $01 . * * * \mathrm{p}<.001$

يتضـح من جدول (14) أن معامل التحديد= 0.111 أي أن الهيكل التتظيمي يفسر 11.1\% مـن التغيرات الحاصلة في الإبداع الإداري، كما يبين الجدول تحليل التباين والذي يمكن التعرف من خلاله على الدلالمة الإحصائية للقوة المعنوية للنموذج عن طريق إحصائية ف (F)= 35.225 ومعنوية الدلالة الحسابية (0.000) مما يؤكد الدلالة الإحصائية لنموذج الانحدار الخطي من الناحية الإحصائية وبالتالي يعتبر النموذج ذا دلالة إحصائية في مجمله. هذا ويشير الجدول إلى أن قيمة تأثير الهيكل التتظيسي تعادل

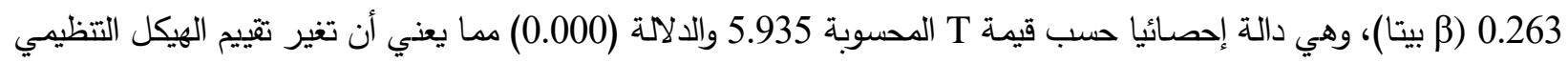

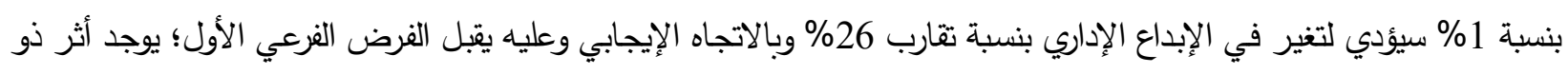
دلالة إحصائية للهيكل التظيمي في الإبداع الإداري. وتتفق نتائج الدراسة مع دراسة الجندي وآخرون (2018) وسركيس (2018). 2. 2 2 الفرض الفرعي الثاني يوجد أثر ذو دلالة إحصائية للوائح والتعليمات المنظمة في الإبداع الإداري للعاملين بالثركات السياحية جدول (15): تحليل الاتحدار الخطي البسيط لأثر اللوائح والتعليمات المنظمة على الإبداع الإداري للعاملين

\begin{tabular}{|c|c|c|c|c|c|}
\hline \multicolumn{6}{|c|}{$\mathrm{R}^{2}=0.046 ; \mathrm{SEE}=0.45180 ; \mathrm{F}=14.332 ;$ ANOVA's Test sig. $=0.000$} \\
\hline المغوية & قيمة اختبار T & معاملات الانحدار & خطأ معياري & غعير القياسية الاندار & 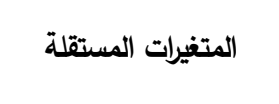 \\
\hline .000 & 16.375 & & 192 & 3.139 & المقدار الثابت \\
\hline ****.000 & 3.786 & .223 & .060 & .227 & اللوائح والتعليمات المنظمة \\
\hline
\end{tabular}

*p <.05.**p<. $01 . * * * \mathrm{p}<.001$

معادلة الانحدار للإبداع الإداري= 227+3.139+227. اللوائح والتعليمات المنظمة تم قبول الفرض الفرعي الثناني

يتضـح من جدول (15) أن معامل التحديد= 046، أي أن اللوائح والتعليمات المنظمـة بشركات السياحة تقسر فقط 4.6\% من

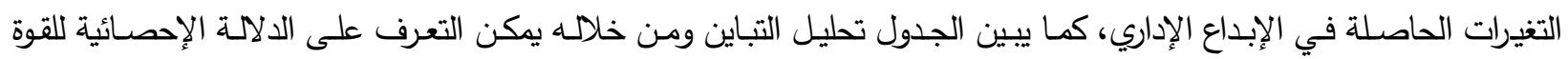

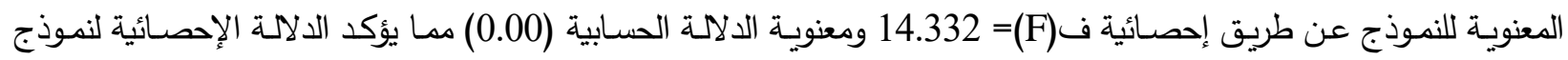
الانحدار الخطى من الناحية الإحصائية وبالتالي يعتبر النموذج ذو دلائلة إحصائية في مجمله. كما يشير الجدول إلى أن قيمة تأثير

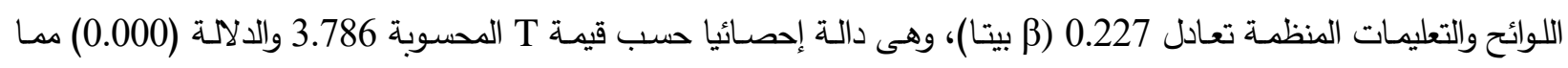

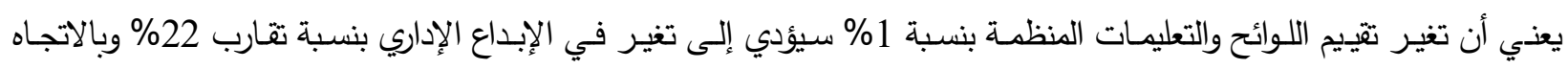
الإيجابي؛ وبناء عليه يقبل الفرض الفرعي الثاني: يوجد أثز ذو دلالة إحصائية للوائح والتعليمات المنظمة في الإبداع الإداري للعاملين

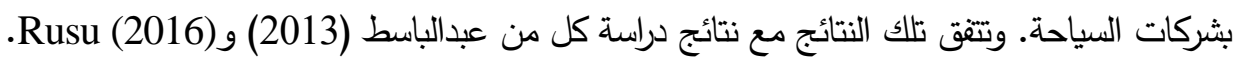


يوجد أثر ذو دلالة إحصائية للمشاركة في اتخاذ القرار في الإبداع الإداري للعاملين بالثركات السياحية

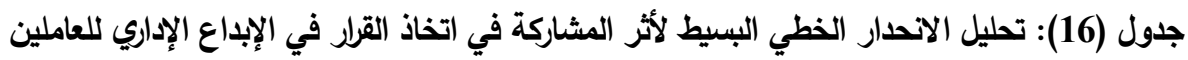

\begin{tabular}{|c|c|c|c|c|c|}
\hline \multicolumn{6}{|c|}{$\mathrm{R}^{2}=0.081 ; \mathrm{SEE}=0.44360 ; \mathrm{F}=25.092 ;$ ANOVA's Test sig. $=0.000$} \\
\hline $\begin{array}{l}\text { المعنوية } \\
\text { Sig }\end{array}$ & 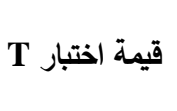 & معاملات الاتحدار & الخطأ المعياري & غعير القياسية الاحدار & 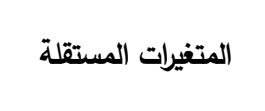 \\
\hline .000 & 17.839 & & .169 & 3.020 & 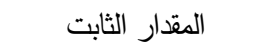 \\
\hline${ }^{* * * *} .000$ & 5.009 & .290 & .050 & .250 & المشاركة في اتخاذ القرار \\
\hline
\end{tabular}

$* \mathrm{p}<.05 . * * \mathrm{p}<.01 . * * * \mathrm{p}<.001$

يتضح من جدول (16) أن معامل التحديد= 0.081، أي أن المشاركة في اتخاذ القرار بشركات السياحة تفسر فقط 8.1\% من التغيرات الحاصلة في الإبداع الإداري، كما يبين الجدول تحليل التباين الذي يتم من خلالهه التعرف على الدلالمة الإحصائية للقوة

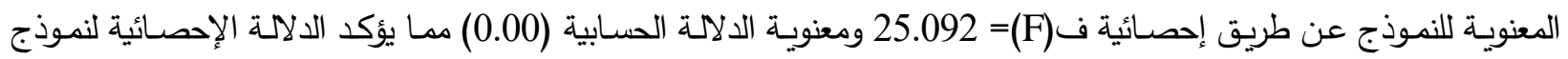

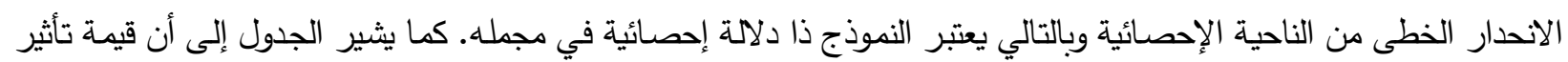

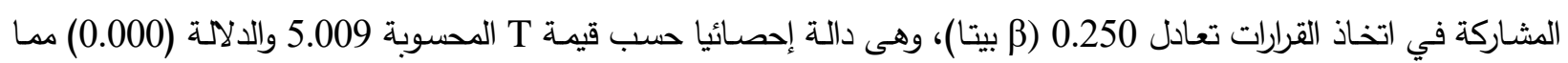

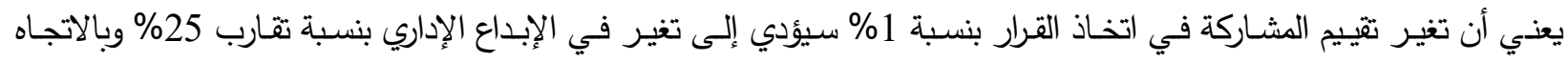
الإيجابي وبناء عليه يقبل الفرض الفرعي الثالث : يوجد أثر ذو دلالة إحصائية للمشاركة في اتخاذ القرار في الإبداع الإداري للعاملين بشركات السياحة. وتتثق هذه النتيجة مع نتائج دراسة كل من عبدالباسط (2013) وأحمد (2018).

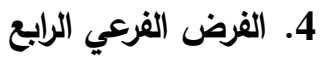

يوجد أثر ذو دلاةة إحصائية للتكنولوجيا في الإبداع الإداري للعاملين بالشركات السياحية. جدول (17): تحليل الانحار الخطي البسيط لأثر التكنولوجيا في الإبداع الإداري للعاملين

\begin{tabular}{|c|c|c|c|c|c|}
\hline \multicolumn{6}{|c|}{$\mathrm{R}^{2}=0.135 ; \mathrm{SEE}=0.43020 ; \mathrm{F}=44.018 ;$ ANOVA's Test sig. $=0.000$} \\
\hline المغوية & ق قيمة اختبار T & معاملات الانحدار & المعياري & غعاملات الاندار & المتغيرات المستقلة المتلة \\
\hline .000 & 23.172 & & .130 & 3.013 & 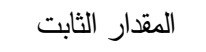 \\
\hline$* * * .000$ & 6.635 & .372 & .035 & .231 & التكنولوجيا \\
\hline \multicolumn{6}{|c|}{ معادلة الانحدار للإِبداع الإداري= 3.013+231. التكنولوجيا } \\
\hline
\end{tabular}

$* \mathrm{p}<.05 . * * \mathrm{p}<.01 . * * * \mathrm{p}<.001$

يتضـح من جدول (17) أن معامل التحديد= 0.135، أي أن عامل التكنولوجيا بشركات السياحة تقسر فقط 13.5\% من التغيرات الحاصلة في الإبداع الإداري، كما يبين الجدول تحليل التباين حيث يتم من خلالمه التعرف على الدلالـة الإحصـائية للقوة المعنويـة

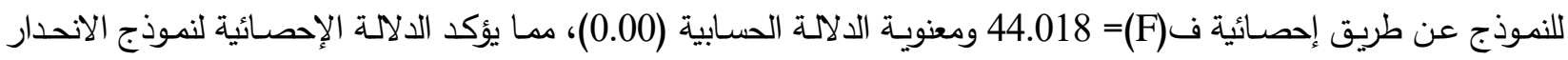
الخطى من الناحية الإحصائية وبالتالي يعتبر النموذج ذا دلالة إحصائية في مجمله. كما يشير الجدول إلى أن قيمة تأثير التكنولوجيا تعادل 0.231 (3 بيتا)، وهى دالة إحصائيا حسب قيمة T المحسوبة 6.635 والدلالة (0.000) مما يعني أن تغير تتييم التكنولوجيا بنسبة 1\% سيؤدي إلى تغير في الإبداع الإداري بنسبة تقارب 23\% وبالاتجاه الإيجابي وبناء عليه يقبل الفرض الفرعي الرابع: يوجد أثر ذو دلالة إحصائية للتكنولوجيا في الإبداع الإداري للعاملين. وتتفق هذه النتائج مع دراسة كل من السعيد (2018) و (2019) al 
5. 5 الفرض الفرعي الخامس

يوجد أثر ذو دلالة إحصائية للتدريب في الإبداع الإداري للعاملين بالثركات السياحية. جدول (18): تحليل الانحار الخطي البسيط لأثر التسريب في الإبداع الإداري للعاملين

\begin{tabular}{|c|c|c|c|c|c|}
\hline \multicolumn{6}{|c|}{$\mathrm{R}^{2}=0.077 ; \mathrm{SEE}=0.44447 ; \mathrm{F}=23.926 ;$ ANOVA's Test sig. $=0.000$} \\
\hline المعنوية & قيمة اختبار T & معاملات الانحار & الخطأ المعياري & معاملات الانحار & المتغيرات المستقلة \\
\hline .000 & 25.714 & & .127 & 3.253 & الدقدار الثابت \\
\hline${ }^{* * * *} .000$ & 4.891 & .283 & .035 & .169 & التتربب \\
\hline
\end{tabular}

${ }^{*} \mathrm{p}<.05 . * * \mathrm{p}<.01 . * * * \mathrm{p}<.001$

يتضح من جدول (18) أن معامل التحديد= 0.077، أي أن عامل التدريب بشركات السياحة يفسر فقط 7.7\% من التغيرات الحاصلة في الإبداع الإداري، كما يبين الجدول تحليل التباين الذي يتم من خلالهه التعرف على الدلالة الإحصائية للقوة المعنويـة للنموذج عن هن طريق إحصائية ف(F)= 23.926 ومعنوية الدلالة الحسابية (0.00) مما يؤكد الدلالة الإحصائية لنموذج الاتحدار الخطى من الناحية الإحصائية وبالتالي يعتبر النموذج ذا دلالة إحصائية في مجمله. كما يشير الجدول إلى أن قيمة تأثير التدريب تعادل 0.169 (م بيتا)،

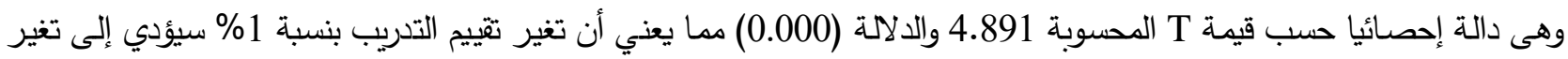
في الإبداع الإداري بنسبة تقارب 16\% وبالاتجاه الإيجابي وبناء عليه يقبل الفرض الفرعي الخامس: يوجد أثر ذو دلالمة إحصائية للتدريب في الإبداع الإداري للعاملين بشركات السياحة. وهى نتائج تتفق مع دراسة كل من(2017) Sawinska و حفصي (2018)

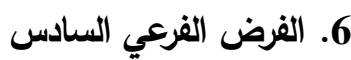

يوجد أثر ذو دلالة إحصائية للمكافآت والحوافز في الإبداع الإداري للعاملين بالثركات السياحية.

جدول (19): تحليل الانحار الخطي البسيط لأثر المكافآت والحوافز في الإبداع الإداري للعاملين

\begin{tabular}{|c|c|c|c|c|c|}
\hline \multicolumn{6}{|c|}{$\mathrm{R}^{2}=0.101 ; \mathrm{SEE}=0.43858 ; \mathrm{F}=31.979 ;$ ANOVA's Test sig. $=0.000$} \\
\hline Sig المعنوية Sig & قيمة اختبار T & معاملات الانحار & الخطأ المعياري & معاملات الانحار غير & 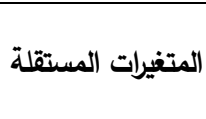 \\
\hline .000 & 30.886 & & .106 & 3.277 & المقدار الثابت \\
\hline ****.000 & 5.655 & .323 & .031 & .176 & المكافآت والحوافز \\
\hline \multicolumn{6}{|c|}{ 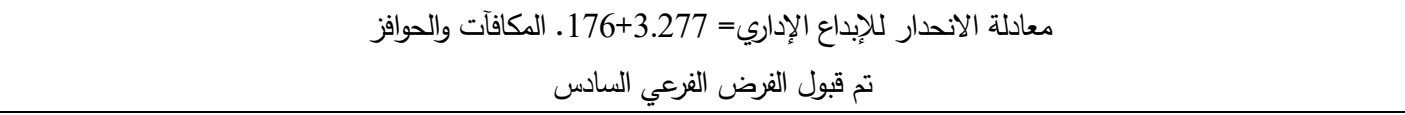 } \\
\hline
\end{tabular}

$* \mathrm{p}<.05$. . *** $<$. $01 . * * * \mathrm{p}<.001$

يتضـح من جدول (19) أن معامل التحديد= 0.101، أي أن عامل المكافآت والحوافز يفسر فقط 10\% من التغيرات الحاصلة في الإبداع الإداري، كما يبين الجدول تحليل التباين حيث يتم من خلاله التعرف على الدلالة الإحصائية للقوة المعنوية للنموذج عن طريق

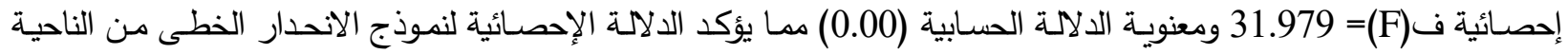
الإحصائية وبالتالي يعتبر النموذج ذا دلالة إحصائية في مجمله. كما يشير الجدول إلى أن قيمة تأثير المكافآت والحوافز تعادل 0.179 (3 بيتا)، وهى دالة إحصائيا حسب قيمة T المحسوبة 5.655 والدلالة (0.000) مما يعني أن تغير تثييم المكافآت والحوافز

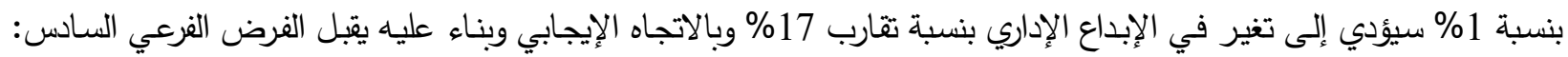
يوجد أثر ذو دلالمة إحصـائية للمكافآت والحوافز في الإبـداع الإداري للعاملين. وتتفق تلك الإنتائج مـع نتائج عبدالباسط (2013) 
7.

يوجد أثر ذو دلالة إحصائية لظروف العمل في الإبداع الإداري للعاملين بالثركات السياحية. جلول (20): تحليل الانحدار الخطي البسيط لأثر ظروف العمل في الإبداع الإداري للعاملين

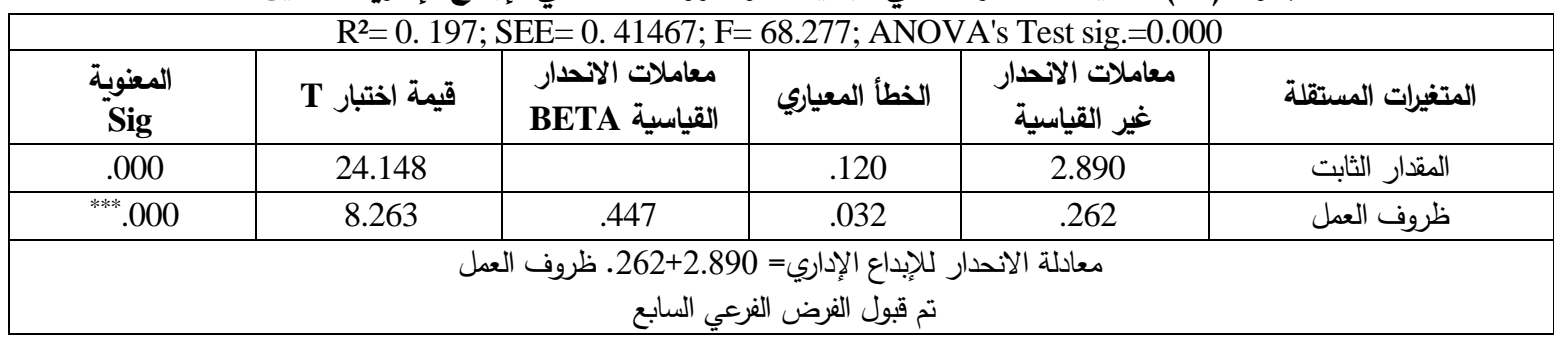

${ }^{*} \mathrm{p}<.05 .{ }^{* *} \mathrm{p}<.01 .{ }^{* * *} \mathrm{p}<.001$

يتضـح من جدول (20) أن معامل التحديد= 0.197، أي أن عامل ظروف العمل بشركات السياحة يفسر فقط 19\% من التغيرات

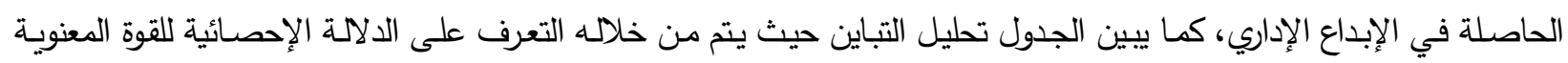

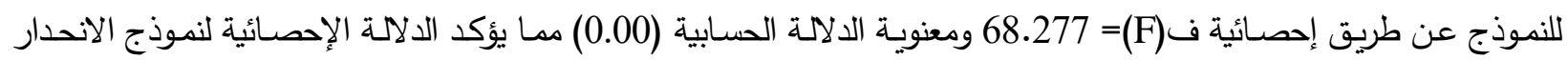
الخطى من الناحية الإحصائية وبالتالي يعتبر النموذج ذا دلالة إحصائية في مجمله. كما يشير الجدول إلى أن قيمة تأثير ظروف

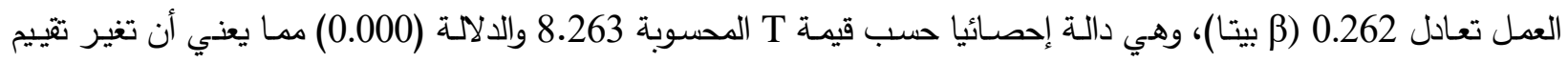

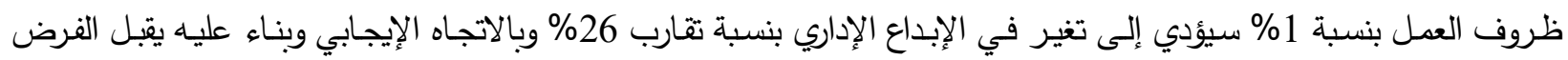

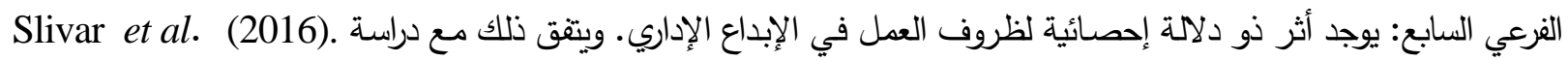
وأحمد (2018). الفرض الرئيسي الثاني يوجد فروق معنوية في تقييم أفراد العينة لبيئة العمل حسب المتغيرات الايموغرافية (النوع، الحالتة الاجتماعية، السن، المستوى

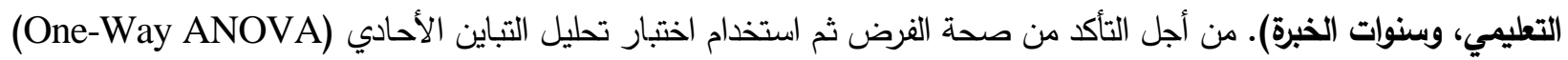
لمقارنة الاختلافات في تتييم متغيرات الدراسة طبقاً للعوامل الديموغرافية.

جدول (21): تحليل التباين الأحادي ANOVA لمقارنة الاختلافات في تقييم بيئة العمل طبقاً للعوامل الديموغرافية

\begin{tabular}{|c|c|c|c|c|c|c|}
\hline المعنوية & قالحسيمة (ف) & متوسط & درجات الحرية & المربعات & مصدر التباين & العوامل الديموغرافية \\
\hline .543 & .974 & .245 & 75 & 18.341 & بين المجموعات & \multirow{3}{*}{ النوع - } \\
\hline & & .251 & 200 & 50.221 & داخل المجموعات & \\
\hline & & & 275 & 68.562 & الإجمالى & \\
\hline \multirow[t]{3}{*}{${ }^{*} .031$} & 1.411 & .448 & 75 & 33.567 & بين المجموعات & \multirow{3}{*}{ الحالة الاجتماعية } \\
\hline & & .317 & 200 & 63.429 & داخل المجموعات & \\
\hline & & & 275 & 96.996 & الإجمالي & \\
\hline \multirow[t]{3}{*}{${ }^{* *} .001$} & 1.797 & 1.172 & 75 & 87.896 & بين المجموعات & \multirow{3}{*}{ 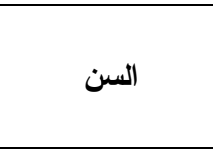 } \\
\hline & & .652 & 200 & 130.405 & داخل المجموعات & \\
\hline & & & 275 & 218.301 & الإجمالي & \\
\hline \multirow[t]{3}{*}{.100} & 1.266 & .159 & 75 & 11.911 & بين المجموعات & \multirow{3}{*}{ المستوي التطليمي } \\
\hline & & .125 & 200 & 25.086 & داخل المجموعات & \\
\hline & & & 275 & 36.996 & الإجمالي & \\
\hline \multirow[t]{3}{*}{${ }^{* *} .002$} & 1.688 & 1.958 & 75 & 146.827 & بين المجموعات & \multirow{3}{*}{ سنوات الخبرة } \\
\hline & & 1.160 & 200 & 231.999 & داخل المجموعات & \\
\hline & & & 275 & 378.826 & الإجمالي & \\
\hline
\end{tabular}

يوضح جدول (21) الدلالة المعنوية للمتغيرات الديموغرافية التالية (الحالة الاجتماعية، السن وسنوات الخبرة) (0.03")، (0.001" (")")، (0.002") على التوالي وهى بذلك أقل من القيمة المعنوية (0.05) مما يؤكد على تأثيرهم الواضح في المتغير المستقل (بيئة العمل) 
بشركات السياحة ، ولذا يمكن صياغة الفرض الثاني: يوجد فروق مغنويـة في تقييم العاملين لبيئة العمل فقط حسب المتغيرات

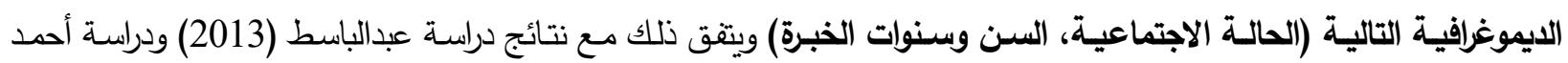
(2018) اللتين أكدا على وجود فروق دالة بين بعض عناصر بيئة العمل تعزى لعامل السن ونوع العمل الذي يمارسـ العاملون

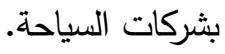
الفرض الرئيسي الثالث يوجد فروق معنويـة في تقييم أفراد العينـة للإبـاع الإداري حسب المتغيرات الديموغرافية (النـوع، الحالة الاجتماعية، السن، (المستوى التعليمي، وسنوات الخبرة). جدول (22): تحليل التباين الأحادي ANOVA لمقارنة الاختلافات في تقييم الإبداع الإداري طبقاً للعوامل الديموغرافية

\begin{tabular}{|c|c|c|c|c|c|c|}
\hline المعنوية & قالمسوبة (ف) & المربعات & درجات الحرية & المربعات & مصدر التباين & الديموغرافية \\
\hline \multirow[t]{3}{*}{.248} & 1.164 & .284 & 37 & 10.508 & بين المجموعات & \multirow{3}{*}{ النوع } \\
\hline & & .244 & 238 & 58.053 & داخل المجموعات & \\
\hline & & & 275 & 68.562 & الإجمالي & \\
\hline \multirow[t]{3}{*}{.316} & 1.109 & .386 & 37 & 14.265 & بين المجموعات & \multirow{3}{*}{ الاجتماعية } \\
\hline & & .348 & 238 & 82.731 & داخل المجموعات & \\
\hline & & & 275 & 96.996 & الإجمالي & \\
\hline \multirow[t]{3}{*}{.235} & 1.177 & .912 & 37 & 33.759 & بين المجموعات & \multirow{3}{*}{ السن } \\
\hline & & .775 & 238 & 184.542 & داخل المجموعات & \\
\hline & & & 275 & 218.301 & الإجمالي & \\
\hline \multirow[t]{3}{*}{${ }^{* * *} .002$} & 1.934 & .231 & 37 & 8.551 & بين المجموعات & \multirow{3}{*}{ التعليمي } \\
\hline & & .120 & 238 & 28.446 & داخل المجموعات & \\
\hline & & & 275 & 36.996 & الإجمالي & \\
\hline \multirow[t]{3}{*}{$* * .040$} & 1.496 & 1.932 & 37 & 71.467 & بين المجموعات & \multirow{3}{*}{ سنوات الخبرة } \\
\hline & & 1.291 & 238 & 307.359 & داخل المجموعات & \\
\hline & & & 275 & 378.826 & الإجمالي & \\
\hline
\end{tabular}

يبين جدول (22) الدلالة المعنوية للمتغيرين الديموغرافيين المستوى التعليمي (0.002) "* وسنوات الخبرة (0.040) **" على التوالي وهما بذلك أقل من القيمة المعنوية (0.05) مما يؤكد على تأثيرهما الواضح في المتغير التابع (الإبداع الإداري)، وهى نتيجة تؤكد أن أن أبعاد الإبداع وطرق تطبيقه إداريـا تتأثثر بثكل كبير بالمستوى التعليمي للعاملين أي كلما ارتفع المستوى التعليمي وزادت أسـاليب التطوير الفردي من تدريب وتعلم لأساليب تكنولوجية متطورة ووسائل حديثة غير تتليدية لمواكبة التطورات في المجال السياحي أنعكس ذلك بقوة ويؤثر في مظاهر الإبداع المؤسسي (Aas, 2016; Sen, 2017)، وكنلك بالنسبة لتأثير سنوات الخبرة في القدرة

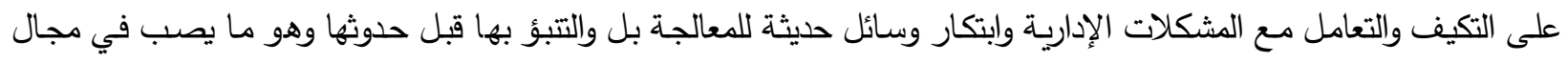
الخبرة والمعرفة (Zonetek, 2016; Marušić et al., 2019). لذلك يمكن صياغة الفرض الثالث بأنه يوجد فروق معنويـة في تقييم العاملين للإبداع الإداري فقط حسب المتغيرات الإيموغرافية التالية (المستوى التعليمي وسنوات الخبرة). اتفقت تلك النتائج مع دراسة عبدالباسط (2013). واختلفت مع بعض الدراسات الأخرى التي بينت أنه لا توجد فروق ذات دلالة إحصائية بين أجوبة أفراد العينة حول تحديد أساليب الإبداع الإداري تعزو لمتغير المستوى التعليمي كدراسة كل من السعيد (2018) وحفصي (2018). مماسبق يوضح الثكل (ا) التالى نتائج اختبار صحة الإدري لفروض. 


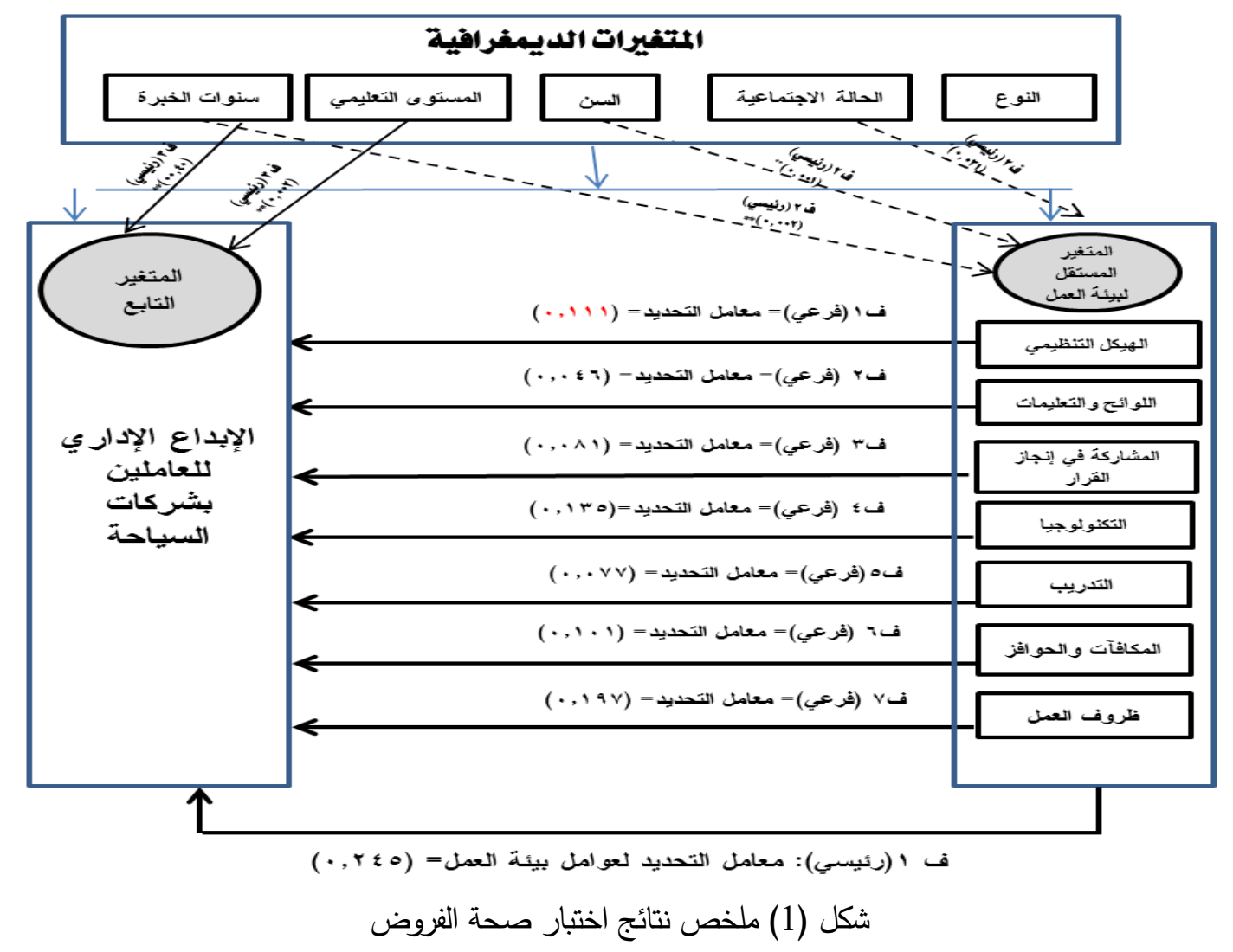

النتائج

تمثل بيئة العمل أحد التحديات الرئيسية التي تواجهها الثركات السياحية في الوقت الراهن مما يؤكد أهمية تهيئتها حتى تكون داعمة

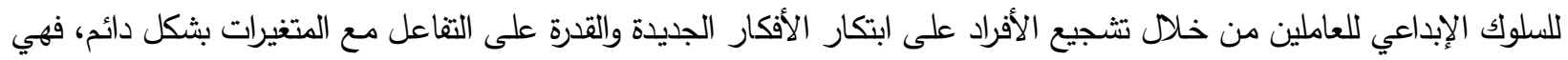

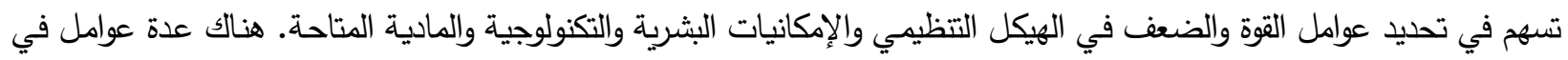

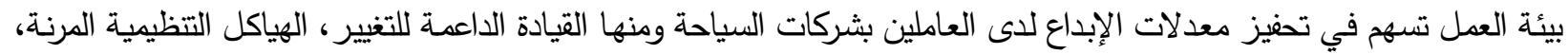

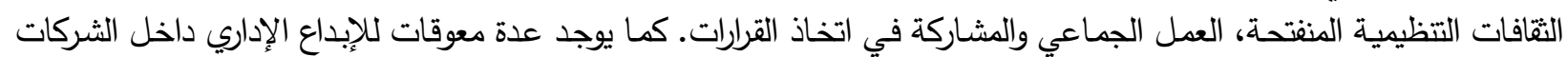

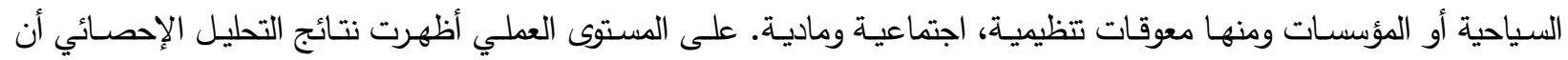

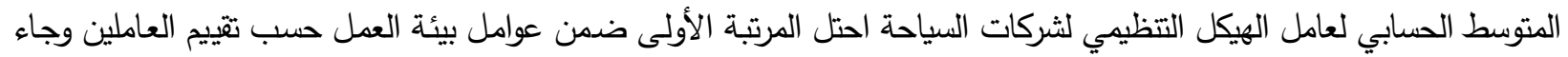

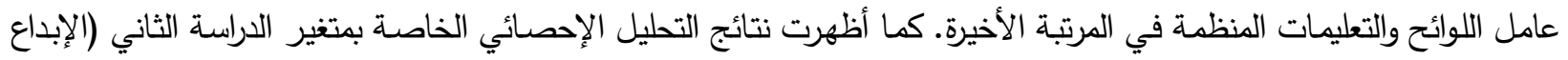

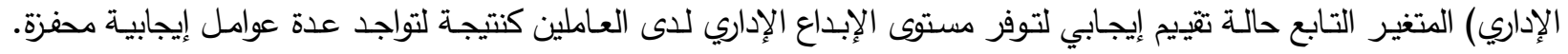

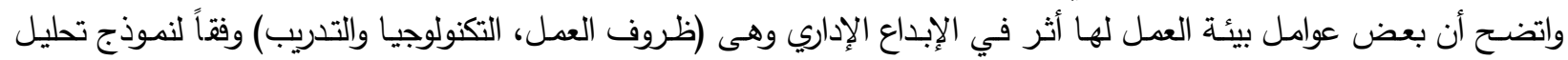

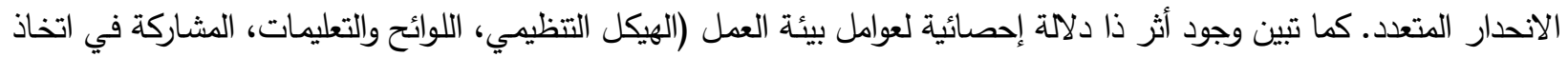

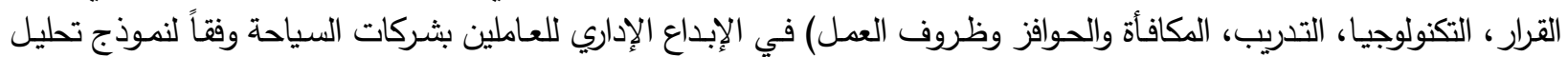

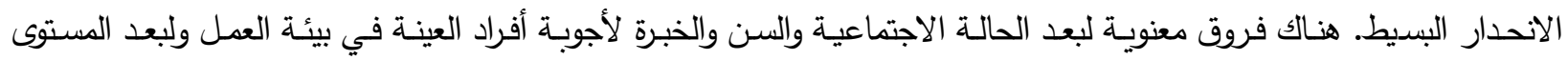

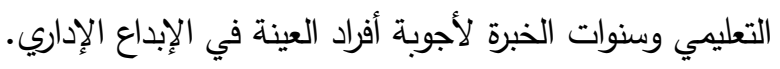

التوصيات " توفير بيئة عمل مناسبة داخل الشركات السياحية المصرية لدعم عنصر الإبداع الإداري من خلال تبسيط إجراءات العمل الداخلية بالثركات السياحية على مستوى (الهيكل التتظيمي، اللوائح والتثدد في المسائل الثكلية، الابتعاد عن المركزية) لأنية الأن البيئة المواتية للعمل لها أكبر أثر في الإبداع.

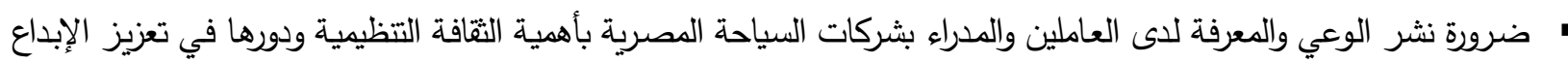

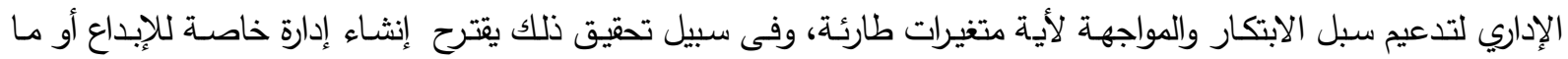


يسمى (بنك الأفكار) وتكون مسئولة عن تتمية مهارات الإبداع لاى العاملين، تبنى الأفكار الإبداعية لهم والعمل على تطبيقها،

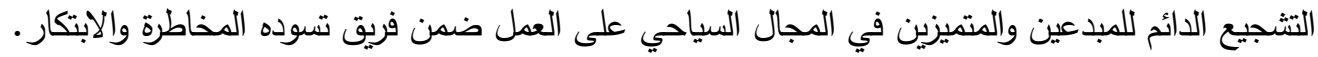

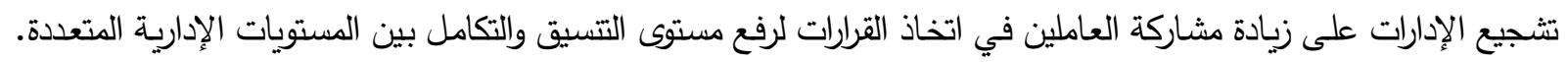

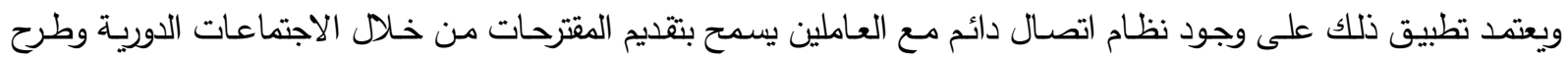
الأفكار المبدعة واستخدام أساليب التفكير المشجعة على الإبداع الجماعي في الثركات السياحية لزيادة كفاءة العاملين الإبداعية.

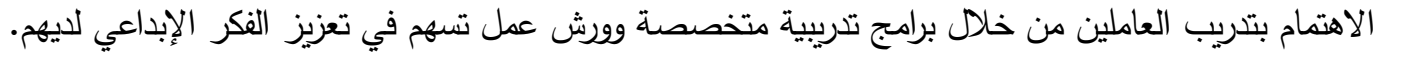

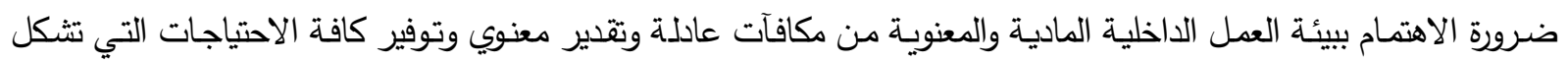

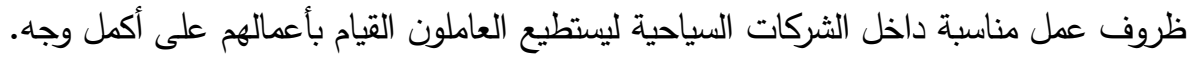

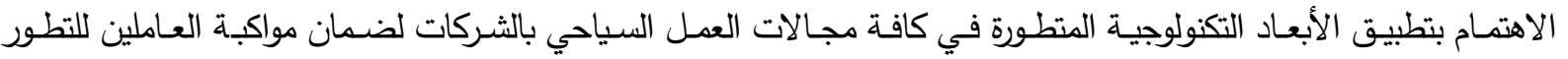
التكنولوجي المستمر ولتطوير خبراتهم لما لها من تأثير في مستويات الإبداع الإداري.

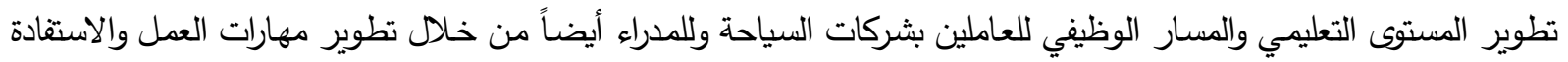
من ذوى الخبرات.

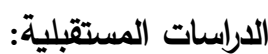

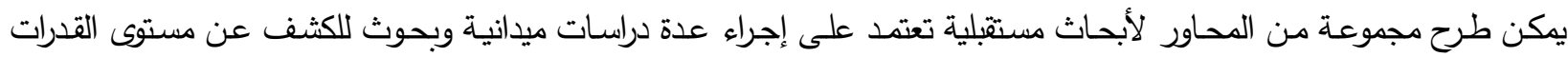

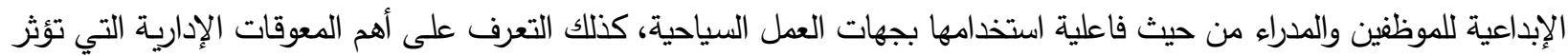

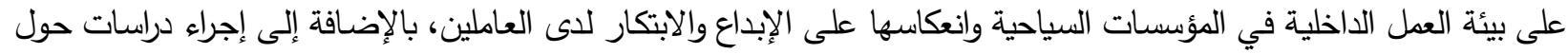

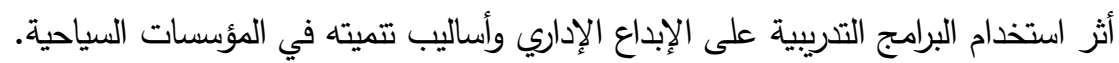
" أحد، مؤيد الثيخ (2018)، "دور التفكير الإبداعي على التخطيط الاستراتيجي: حالة عملية قطاع السياحة في قطاع غزة"، رسالة ماجستير

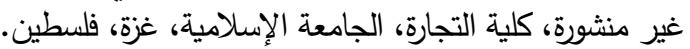

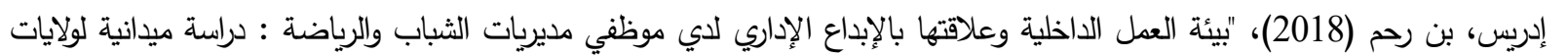

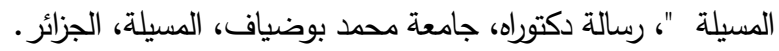
ه إسماعيل، مودة إسماعيل (2014) ، "أثز بيئة العمل على الإبداع الإداري: دراسة حالة جالة جامعة السودان للعلوم والتكنولوجيا "، رسالة ماجستير

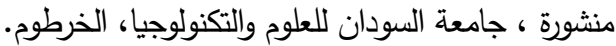
"الأخرس, جبر سيد عبدالله (2016)، "الإدارة الاستراتيجية وفق النموذج الإنجان الأوروبي للتميز وأثرها على الإبداع الإداري في القطاع الحكومي

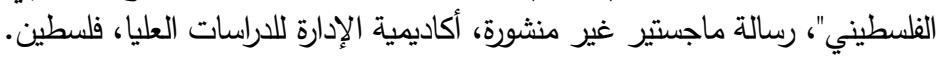

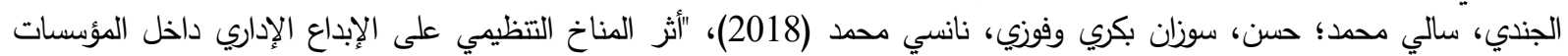

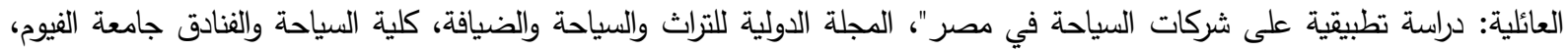

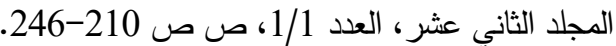
ه الحربي، موسي محمد (2003)، "أثز متغيرات البناء التتظيمي والمتغيرات الثخصية على الثئل الإبداع الإداري لدى المدراء في الأجهزة الحكومية

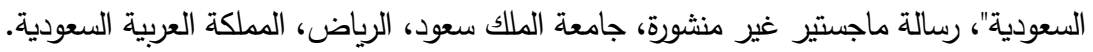
" الحمداني، موفق (2006)، مناهج البحث العلمي، مؤسسة الوراق للنشر ،عمان، الأردن.

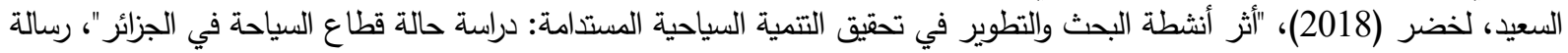

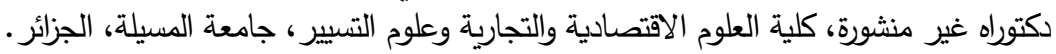

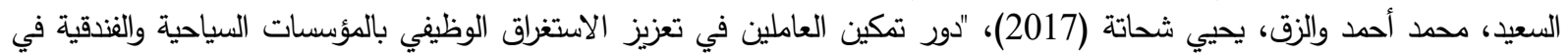

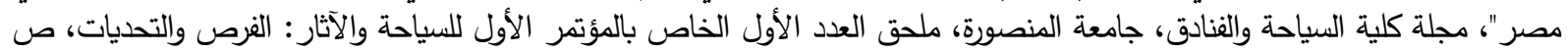

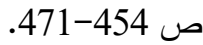
ه الثاعر , عماد سعيد (2017)، "ممارسات القيادة الأخلاقية وعلاقتها بتحقيق الإبداع الإداري: دراسة ميدانية على الجامعات الفلسطينية في

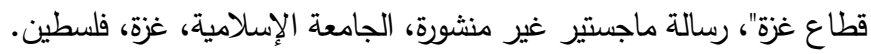

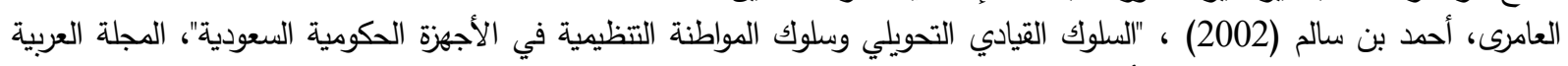

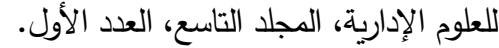

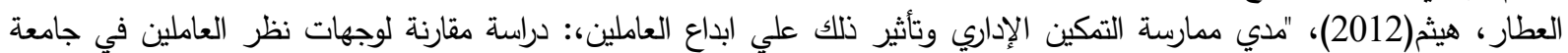

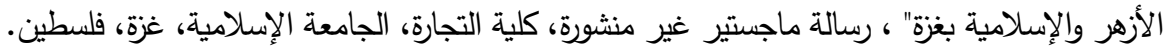


هالقحطاني, سعيد (2012)، "بيئة العمل الداخلية وعلاقتها بمعنويات العاملين", رسالة ماجستير منشورة، جامعة نايف للعلوم الأمنية, الرياض، المملكة العببية السعودية.

اللامي، غسان قاسم وحسين، يسري محمد (2009)، "قياس مؤشرات الإبداع في الإدارات الفندقية: فلسطين ميريديان وعشتار شيراتون-دراسة

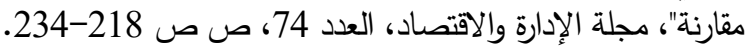

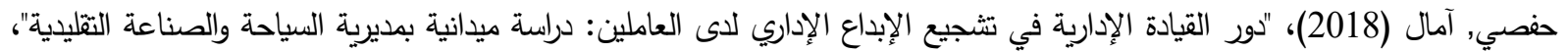

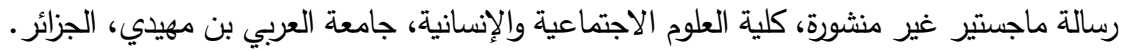

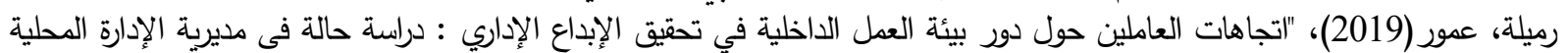

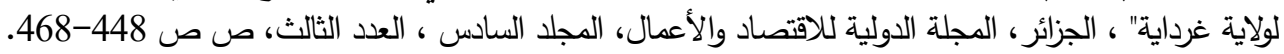

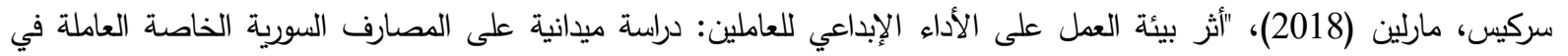
دمشق"، رسالة ماجستير غير منشورة، الجامعة الاقتراضية السورية، سوريا.

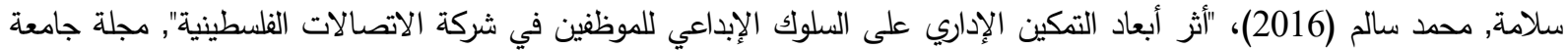

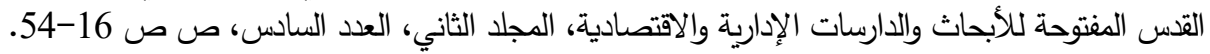

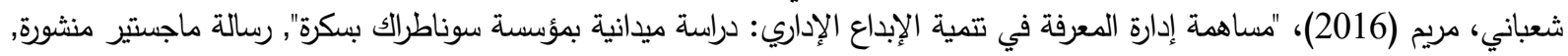

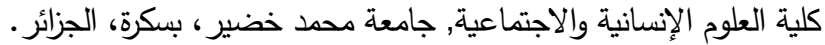

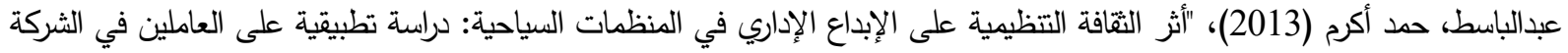

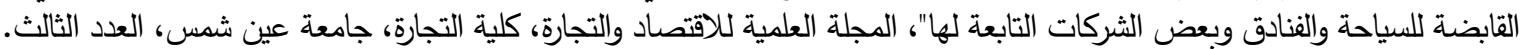

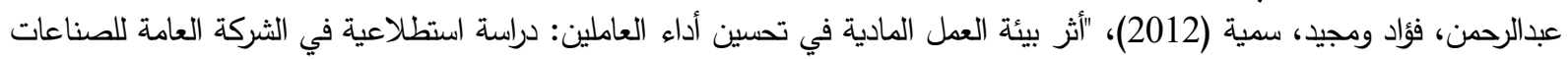

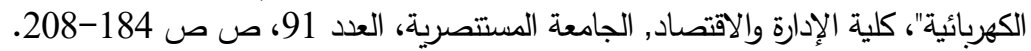

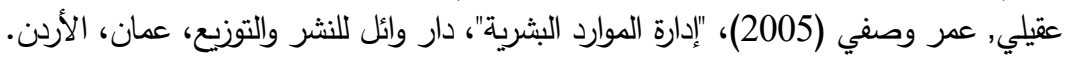

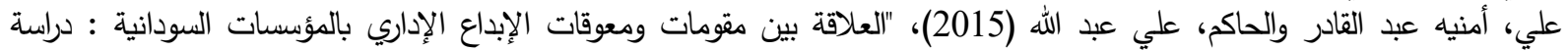

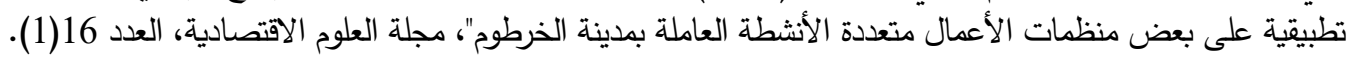

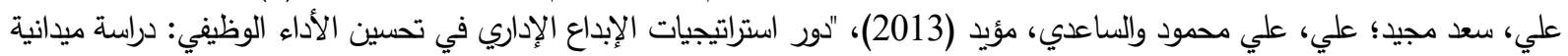

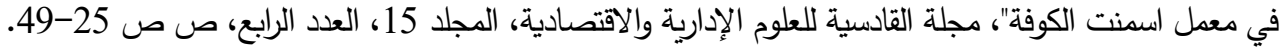

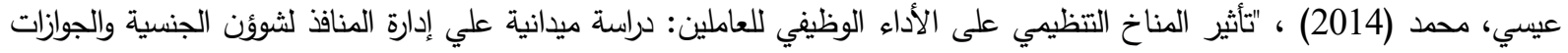

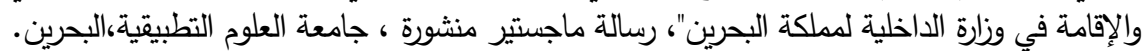
محمدية، عمر (2016)، "أثر التككين الوظيفي في السلوك الإبداعي لاي العاملين في هيئة تتثيط السياحة الأردنية"، رسالة ماجستير منشورة، كلية الأعمال، جامعة الثرق الأوسط، الأردن. هحمود, دجلة (2013)، "تأثير أخلاقيات الوظيفة في الإبداع الإداري: بحثث ميداني في عينة من المصارف العراقية"، مجلة التقني، المجلد

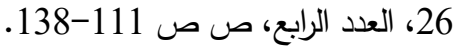
هينة، مفاتيح (2018)، أثر الابتكار السياحي على التتمية السياحية، رسالة دكتوراه منشورة ، كلية العلوم الاقتصادية والتجارية وعلوم التسبير ، جامعة ورقلة، الجزائر.

\section{المراجع الأجنبية}

- Aas, T., (2016), " Open Service Innovation: The Case of Tourism Firms in Scandinavia", Journal of Entrepreneurship, Management and Innovation, Vol. 12, Issue 2, pp. 53-76.

- Abou shouk, M., Lin, W. and Megicks, P., (2016), " Using Competing Models to Evaluate the Role of Environment of Pressures in e commerce Adaption by Small and Medium Sized Travel Agents in a Developing Country", Tourism Management, 52,pp. 327-339 .

- Bolgova, V.; Makushkin, S.; Povorina, E. and Duply, E. (2016), "The Innovative Control Management of Travel Companies", International Review of Management and Marketing, Vol. 6, No. 56, pp. 79-84.

- Hassan, D., Yahiya, N., Mohammed, A. and Gaafar, H., (2018) "Entrepreneurship: A Strategy for Creating Innovative Tourism Products in Egyptian Travel Agencies", Journal of The Faculty of Tourism and Hotels. University of Sadat-City, Vol. 2, Issue 1.

- Hjalager, A. (2018) "Chapter 11 Suppliers as Key Collaborators for Sustainable Tourism Development" In: Liburd, D.J. \& Edwards, D.D. (ed). Oxford: Goodfellow Publishers.

- Izquierdo, L.M., Rodriguez, A. R. and Such, D. M, (2018), " The Challenge of Long Term Tourism Competitiveness in the Age of Innovation: Spain as a Case Study", Journal of Regional Research, (42), pp. 13-34. 
- Jayaweera, T. (2015), "Impact of Work Environmental Factors on Job Performance: A Study of Hotel Sector in England", International Journal of Business and Management, Vol. 10, No. 3, p. 271-278.

- Marušić, Z.; Aleksić,A.; Pejić,M.;Bach, M. and Zoroja,J., (2019), "Determinants of Innovati Technologies and Enterprise Readiness on in Hotel and Travel Agency Service Industry : Impact of Information and Communication Technologies and Enterprise", Readiness Interdisciplinary Description of Complex Systems ,Vol .17,No.1-B, pp. 209-225.

- Rusu, B. (2016), "The Impact of Innovation on the Business Model Exploratory Analysis of a Small Travel Agency", Procedia-Social and Behavioral Sciences, Vol. 221, pp. 166-175.

- Sawinska, A., (2017), "Innovations of Travel Agencies in Tourism Services for Seniors ", Tourism in Southern and Eastern Europe, Vol. 4, pp. 511-523.

- Sekaran, U. and Bougie, R. (2009), "Research Methods for Business: A Skills Building Approach", $5^{\text {th }}$ Ed, John Wiley and Son, Sussex, UK.

- Sen, D., Bingol, S. and Vayvay, O. (2017), "Strategic Enterprise Management for Innovative Companies the Last Decade of the Balanced Scorecard", International Journal of Asian Social Science, Vol. 7, No.1, pp. 97-109.

- Slivar, I.; Bozic, S. and Batkovic, A. (2016), "Innovation in Tourism: Perception of Tourism Providers from Croatia and Serbia", Review of Innovation and Competitiveness: A Journal of Economic and Social Research, Vol. 2, No. 4, pp.37-56.

- Taha, A. (2016), "The Impact of Organizational Culture on Creativity and Innovation", Polish Journal of Management Studies, Vol. 14. No. 1, pp. 7-17.

- Teodorescu, N., Stanciou, A., Ravar, A. and Botos, A., (2015)," Creativity and Innovation Source of Competitive Advantage in the Value Chain of Tourism Enterprises", The Oriticaland Applied Economics, Vol. 5, No .1, pp.35-48.

- Tuzunkan, D., (2017), "The Relationship between Innovation and Tourism: The case of Smart Tourism", International of Applied Engineering Research, Vol. 12, No. 23, pp. 14861-14867.

- Zonetek, Z., (2016), "The role of Human Resources in Enhancing Innovation in Tourism Enterprises", Managing Global Transitions, Vol. 14, No.1, pp.55-73.

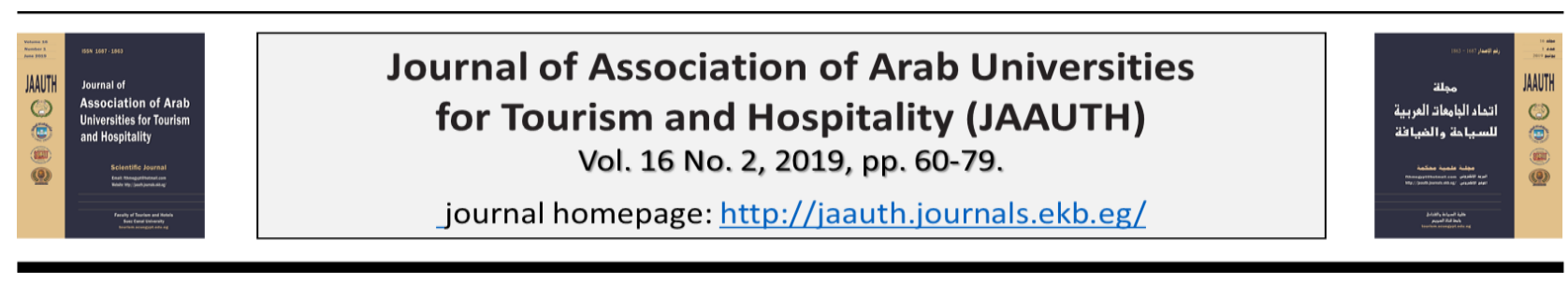

\title{
The Impact of the Work Environment on the Managerial Creativity of Employees in the Egyptian Tourism Companies
}

\author{
Heba Abdel Karim Youssef Zidan \\ Tourism Studies High Institute of Tourism Hotel Management and Monuments Restoration \\ Abou-Quir Alexandria
}

\begin{tabular}{|c|c|}
\hline ARTICLE INFO & English Abstract \\
\hline Ke & \\
\hline & \\
\hline & $\because 14$ \\
\hline $\mathrm{N}$ & viron \\
\hline $\mathrm{C}$ & $\begin{array}{l}\text { The study sheds light on the importance of managerial innovation as a modern } \\
\text { management philosophy that many tourism companies seek to apply to ensure their }\end{array}$ \\
\hline $\mathrm{Cl}$ & on the tourist market. The study population was employees in \\
\hline blities; & stion \\
\hline $\begin{array}{l}\text { Tou } \\
\text { Cor }\end{array}$ & ed to collect data. The 1 \\
\hline Cor & nagement training programs in tourism companies for the benefit of institutional \\
\hline Vol. & lopment based on highlighting the creative skills of managers and \\
\hline Vol & 1 as in the development of the management system in tourism \\
\hline & knesses and problems of the internal work \\
\hline
\end{tabular}

